\title{
Early Agenian rhinocerotids from Wischberg (Canton Bern, Switzerland) and clarification of the systematics of the genus Diaceratherium
}

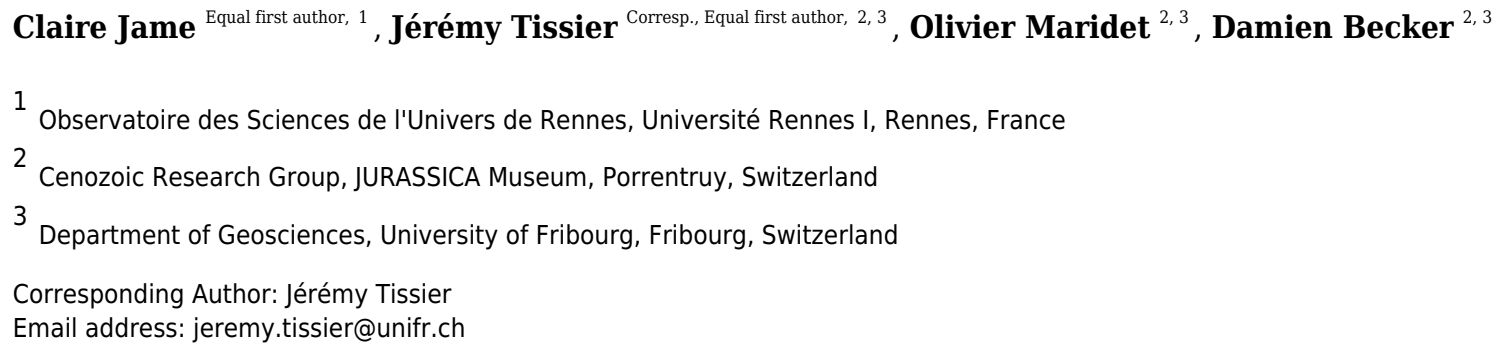

Background. Wischberg is a Swiss locality in Bern Canton which has yielded numerous vertebrates remains from the earliest Miocene (= MN1). It has a very rich faunal diversity, one of the richest in Switzerland for this age. Among all the mammals reported in the original faunal list 70 years ago, three rhinocerotid species were identified. The material consists of two fragmentary skulls, cranial fragments, several mandibles, teeth and postcranial bones, in a rather good state of preservation.

Results. After reexamination of the material from this locality (curated in three different Swiss museums) and comparison with holotype specimens, we show that all rhinocerotid specimens from Wischberg can be referred to two species only. Most of the material can be attributed to the large-sized teleoceratine Diaceratherium lemanense, while only a few specimens, including a skull and mandible, belong to the much smaller sized Pleuroceros pleuroceros. We describe and illustrate for the first time most of these fossil remains. However, the systematics of the genus Diaceratherium is currently controversial, and based on our new observations we consider seven species as valid, though a largescale phylogenetic study should be done in the future to resolve it. The rhinocerotid association found in Wischberg is nonetheless typical of the MN1 biozone, which results from a faunal renewal occurring just before the end of the Oligocene. 


\section{Early Agenian rhinocerotids from Wischberg (Canton}

2 Bern, Switzerland) and clarification of the systematics

3 of the genus Diaceratherium

4

5

6

7

8

Claire Jame ${ }^{1}$, Jérémy Tissier ${ }^{2,3}$, Olivier Maridet ${ }^{2,3}$, Damien Becker ${ }^{2,3}$

${ }^{1}$ Observatoire des Sciences de l'Univers de Rennes, Université Rennes I, Rennes, France

${ }^{2}$ Cenozoic Research Group, JURASSICA Museum, Porrentruy, Switzerland

${ }^{3}$ Department of Geosciences, University of Fribourg, Fribourg, Switzerland

Corresponding Author:

Jérémy Tissier ${ }^{2,3}$

Route de Fontenais 21, Porrentruy, Jura, 2900, Switzerland

Email address: jeremy.tissier@unifr.ch

\section{Abstract}

Background. Wischberg is a Swiss locality in Bern Canton which has yielded numerous vertebrates remains from the earliest Miocene (= MN1). It has a very rich faunal diversity, one of the richest in Switzerland for this age. Among all the mammals reported in the original faunal list 70 years ago, three rhinocerotid species were identified. The material consists of two fragmentary skulls, cranial fragments, several mandibles, teeth and postcranial bones, in a rather good state of preservation.

Results. After reexamination of the material from this locality (curated in three different Swiss museums) and comparison with holotype specimens, we show that all rhinocerotid specimens from Wischberg can be referred to two species only. Most of the material can be attributed to the large-sized teleoceratine Diaceratherium lemanense, while only a few specimens, including a skull and mandible, belong to the much smaller sized Pleuroceros pleuroceros. We describe and illustrate for the first time most of these fossil remains. However, the systematics of the genus Diaceratherium is currently controversial, and based on our new observations we consider seven species as valid, though a large-scale phylogenetic study should be done in the future to resolve it. The rhinocerotid association found in Wischberg is nonetheless typical of the MN1 biozone, which results from a faunal renewal occurring just before the end of the Oligocene.

\section{Introduction}

The Aquitanian Lower Freshwater Molasse (USM, "Untere Süsswassermolasse") record of the Plateau Molasse is characterised within the central and eastern area of the Swiss North Alpine Foreland Basin (NAFB) by the floodplain deposits from the Granitische Molasse Formation, lateral equivalent of the Molasse grise de Lausanne Formation from the western area (Habicht 
40

41

42

43

44

45

46

47

48

49

50

51

52

53

54

55

56

57

58

59

60

61

62

63

64

65

66

67

68

69

70

71

72

73

74

75

76

77

78

79

1987, Berger et al. 2005a, b, Schweizerisches Komitee für Stratigraphie und Landesgeologie

2014). These geological formations yielded many vertebrate localities, unfortunately recording mostly incomplete assemblages and only a few large mammal species (Scherler et al. 2013). However, Agenian land mammal associations are remarkably well documented in the localities of Wischberg (Aquitanian age, MN1 biozone; Schaub \& Hürzeler 1948, Engesser \& Mödden 1997), Engehalde (MN2; Becker et al. 2010) and Wallenried (MN2; Becker et al. 2001, Mennecart et al. 2016).

From the area of Langenthal (Bern Canton, Switzerland), Gerber $(1932,1936)$ first reported fossil rhinocerotids originating from the Wischberg locality (latitude $47.199157894^{\circ}$ /longitude 7.763943664; Fig. 1). A preliminary mammal list was provided by Schaub \& Hürzeler (1948), including Eulipotyphla, Rodentia, Lagomorpha, Cainotheriidae, non-ruminant Artiodactyla, Ruminantia, Tapiridae and Rhinocerotidae. More recently, Lagomorpha have been reviewed by Tobien (1975) and part of large mammals by Becker (2003) and Scherler et al. (2011, 2013). Since the work of Engesser \& Mödden (1997) on the mammal biozonation of the Lower Freshwater Molasse of Switzerland, the mammal assemblage of Wischberg (Table 1) can be considered as one of the most important and complete in the Swiss Molasse Basin, consistently pointing to an early Aquitanian age.

\section{Figure 1:}

General setting of Wischberg locality, Bern Canton, Swiss Molasse basin (MN1, Agenian, earliest Miocene).

(A) Map of a part of Western Europe showing the location of Switzerland. (B) Enlargement of the Aquitanian palaeogeographical context of the Swiss Molasse Basin, with detailed location of Wischberg locality (star symbol).

Table 1:

Mammal assemblage of Wischberg locality, Bern Canton, Swiss Molasse basin (MN1, Agenian, earliest Miocene).

In this work, we first review the description and the identifications of the rhinocerotid material from Wischberg, which were assigned to three species by Schaub \& Hürzeler (1948): the singlehorned and short-limbed teleoceratines Diaceratherium lemanense (Pomel, 1853) and D. asphaltense (Depéret and Douxami, 1902), as well as the small-sized tandem-horned Pleuroceros pleuroceros (Duvernoy, 1853). Second, we examine the systematics of the genus Diaceratherium, which is currently contentious, and the ecological role of the Early Miocene Rhinocerotidae within the large herbivorous mammal communities of Western Europe.

\section{Materials \& Methods}

The fossil materials from Wischberg were discovered between 1931 and 1947 in two pits of Aquitanian mottled marls and sands of the Granitische Molasse (Schaub \& Hürzeler 1948) that 
80 were exploited during the first half of the last century in Langenthal (Bern Canton, Switzerland).

81 The sites are no longer accessible due to anthropogenic developments. The studied material

82 includes twenty-four rhinocerotid specimens (and among them three casts) that are stored in the

83 natural history museums of Bern (Naturhistorisches Museum des Burgergemeinde Bern) and

84 Basel (Naturhistorisches Museum Basel), as well as in the local museum of Langenthal (where

85 the original skull and a mandible of Diaceratherium lemanense are exposed). It is worth to

86 clarify that the original specimens referred to Pleuroceros pleuroceros, except the semilunate

87 NMBE5031537, are lost and the work on this taxon is based on the remaining casts.

88 The rhinocerotid specimens from Wischberg have been described by means of anatomical

89 descriptions, comparative anatomy, and biometrical measurements. The sequence of described

90 dental and osteological features follows Antoine (2002). The dental terminology follows Heissig

91 (1969) and Antoine (2002), while dental and skeletal measurements were taken according to

92 Guérin (1980). The locomotion type is based on the gracility index of the McIII and MtIII (100 x

93 TDdia/L; Guérin 1980).

94 The stratigraphical framework is based on geological time scales and European Land Mammal

95 Ages for the Neogene (Hilgen et al. 2012). Successions of Mammal Neogene units (MN) were

96 correlated by Berger (2011) based on biostratigraphic and magnetostratigraphic data

97 (BiochroM'97 1997, Engesser \& Mödden 1997, Kempf et al. 1997, 1999, Mein 1999, Steininger

98 1999, Agustí et al. 2001).

99 Body masses of the rhinocerotid species found in Wischberg are estimated from dental and

100 postcranial measurements. The equations used to estimate the body mass of rhinocerotids are

101 based on the correlations established for perissodactyls by Legendre (1989), for Rhinocerotidae

102 by Fortelius and Kappelman (1993) and for mammals by Tsubamoto (2014).

103

104 Abbreviations

105 APD antero-posterior diameter, Cc calcaneus, dia diaphysis, dist distal, GI gracility index, H

106 height, I/i upper/lower incisor, L length, M/m upper/lower molar, Mc metacarpal, MHNT

107 Museum d'histoire naturelle de Toulouse, ML Museum Langenthal, MNHN Muséum national

108 d'Histoire naturelle (Paris), Mt metatarsal, NMB Naturhistorisches Museum Basel, NMBE

109 Naturhistorisches Museum der Burgergemeinde Bern, P/p upper/lower premolar, prox proximal,

110 SMNS Staatliches Museum für Naturkunde Stuttgart, TD transversal diameter, W width.

111

112 Results

113 Systematic palaeontology

114

115 Class Mammalia Linnaeus, 1758

116 Order Perissodactyla Owen, 1848

117 Superfamily Rhinocerotoidea Gray, 1821

118 Family Rhinocerotidae Gray, 1821

119 Subfamily Rhinocerotinae Gray, 1821 
120

121

122

123

124

125

126

127

128

129

130

131

132

133

134

135

136

137

138

139

140

141

142

143

144

145

146

147

148

149

150

151

152

153

154

155

156

157

158

Genus Pleuroceros Roger, 1898

Type species: Pleuroceros pleuroceros (Duvernoy, 1853)

Included species: Pleuroceros blandfordi (Lydekker, 1884)

Pleuroceros pleuroceros (Duvernoy, 1853)

Fig. 2-3, Table 2-4

Stratigraphical range: Latest Oligocene (?MP29/30) to Early Miocene (MN1-MN2), western and central Europe (Antoine \& Becker 2013)

Occurrences:

- France: Billy-Base (Allier), ?MN29/30; Gannat, MN1 (type locality); Paulhiac, MN1;

Pyrimont-Challonges, MN1; Saulcet, MN1; Laugnac, MN2; Montaigu-le-Blin, MN2; (Duvernoy 1853, Lavocat 1951, Bonis 1973, Hugueney 1997, Ginsburg \& Bulot 2000, Antoine et al. 2010, Antoine \& Becker 2013, Scherler et al. 2013)

- Germany: Flörsheim, MN2; Pappenheim, MN2 (Schlosser 1902, Heissig 1999)

- Switzerland: Wischberg, MN1 (Schaub \& Hürzeler 1948, Heissig 1999, Becker 2003)

Referred material: Skull with right P1-M3 and left P2-M3 (original specimen lost, cast

NMBE5031553, cast NMB-AS77), fragmented mandible with right p4-m3 and left m1-2 (original lost, cast NMBE5026739, cast NMB-AS78), right semilunate (NMBE5031537, cast NMB-AS3), right McIV (original lost, cast NMB-AS79) from Wischberg (Switzerland, MN1)

\section{Figure 2:}

Pleuroceros pleuroceros (Perissodactyla, Rhinocerotidae) from Wischberg locality, Bern Canton, Swiss Molasse basin (MN1, Agenian, earliest Miocene).

Partial skull NMBE5031553 in lateral (A), dorsal (B), medial (C) and occlusal (D) views and left-side fragment with P2-M3 from the same individual in occlusal (E) view. Mandible fragments NMBE5026739 in labial (F, G), lingual (H, I) and occlusal (J, K) views with p4m3 (right-side fragment) and m1-2 (left-side fragment). Photo credit: Patrick Röschli.

\section{Figure 3:}

Pleuroceros pleuroceros (Perissodactyla, Rhinocerotidae) from Wischberg locality, Bern Canton, Swiss Molasse basin (MN1, Agenian, earliest Miocene).

Right semilunate NMBE5031537 in anterior (A), proximal (B), distal (C), lateral (D) and medial (E) views and right McIV (cast NMB-AS79) in anterior (F), lateral (G), posterior (H), medial (I) and proximal with dorsal toward top (J) views. Photo credit: Patrick Röschli.

Table 2: 
159 Dimensions [mm] of the cheek teeth of Pleuroceros pleuroceros (Perissodactyla,

160 Rhinocerotidae) from Wischberg locality, Bern Canton, Swiss Molasse basin (MN1,

161 Agenian, earliest Miocene).

162 Dimensions in parentheses are estimated.

163

164

Table 3:

165

Dimensions [mm] of the semilunate of Pleuroceros pleuroceros from Wischberg

166 (NMBE5031537) and comparison with other specimens of Pleuroceros and Diaceratherium. Dimensions in parentheses are estimated and those in italics are based on the literature. Localities are indicated below the taxon name and those in bold font are the type localities of the species. The upper line indicates the minimum and maximum dimensions, and the bottom line (when several specimen are used) indicates the average value and the number of specimens (in brackets).

172

173

Table 4:

Dimensions [mm] of the McIV of Pleuroceros pleuroceros from Wischberg (NMB AS79) and comparison with Diaceratherium species (Perissodactyla, Rhinocerotidae). Dimensions in parentheses are estimated and those in italics are based on the literature. Localities are indicated below the taxon name and those in bold font are the type localities of the species. The upper line indicates the minimum and maximum dimensions, and the bottom line (when several specimen are used) indicates the average value and the number of specimens (in brackets).

\section{Description}

Skull. NMBE5031553 is a cast of an incomplete, fragmented and transversally compressed skull comprising a part of the frontals, the area of the right zygomatic arch, the right P1-M3 and the left P2-M3. Few cranial characters are observable. We can note a remarkably curved upwards jugal bearing a processus postorbitalis, an infraorbital foramen situated above the $\mathrm{P} 3$, an anterior border of the orbit reaching the level of the paracone of M1, an anterior base of the zygomatic process high above the M1, and the presence of a processus lacrimalis (Fig. 2A). Mandible. From the fragmented mandible NMBE5026739, the corpus mandibulae (height below $\mathrm{m} 3=71.5 \mathrm{~mm}$ ) does not seem to bear a median sagittal groove (sulcus mylohyoideus). The retromolar space is short and the position of the foramen mandibulae (based on the transverse slimming of the corpus in cross section) is located below the alveolar level (Fig. 2FG). reduced compared with the molars (LP3-4/LM1-3 > 50; Table 2). The dental structures are simple, without secondary enamel folds. The cheek teeth are brachydont (low-crowned), and the roots are long and distinct. The upper cheek teeth lack crista and medifossette. The paracone fold 
199

200

201

202

203

204

205

206

207

208

209

210

211

212

213

214

215

216

217

218

219

220

221

222

223

224

225

226

227

228

229

230

231

232

233

234

235

236

237

238

molariform (sensu Heissig 1969) and lack any crochet, antecrochet and constriction of both protoloph and metaloph. The labial cingulum is reduced to the posterior part of the ectoloph and the lingual cingulum is reduced to the opening of the median valley. On P2-4 the postfossette is narrow and the metaloph is posterolingually oriented. The P1 is much narrower than P2 and triangular in occlusal view (Fig. 2D). On P2, the protocone is as developed as the hypocone, the metaloph is directed posterolingually, and the protoloph is continuous and widely connected with the ectoloph. A crochet is always present on upper molars, but the metaloph is not constricted. The labial cingulum is weak and absent at the base of the paracone fold, whereas the lingual cingulum is reduced to the base of the posterior half of the protocone, reaching the opening of the median valley. The metastyle is long and the metacone fold is absent. On M1-2, the protoloph is slightly constricted and it bears an antecrochet, the metaloph is short and the distal part of the ectoloph is straight. A weak mesostyle is present on M2. The M3 has a roughly triangular occlusal outline, though the ectoloph and metaloph are fused in a characteristic convex ectometaloph without posterior groove. The protoloph is not lingually elongated, without constriction and antecrochet.

Lower teeth. On lower cheek teeth, the labial cingulum is reduced to a thin bulge at the base of the external groove and the lingual one is completely absent (Fig. 2F-G). The external groove is developed and is vanishing above the neck. The trigonid is angular and forms a right dihedron in occlusal view (Fig. $2 \mathrm{H}$ ). The metaconid and the entoconid are not constricted. The posterior valley is $\mathrm{V}$-shaped, but wider on the lower molars than on the premolars. The hypolophid of the lower molars is oblique and there is no lingual groove on the entoconid of m2-3.

Semilunate. The semilunate NMBE5031537 (Fig. 3A-E) is slightly rolled and eroded (Table 3). The medial and lateral facets are not preserved, except for the flat, ovoid, and sagittally elongated proximomedial facet for the scaphoid (Fig. 3E). In proximal view (Fig. 3B), the ulnafacet is lacking and, in anterior view (Fig. 3A), the anterior side is smooth with an acute distal border, high and narrow. The proximal facet is very convex and short sagittally (Fig. 3B). The magnum-facet is roughly flat in its anterior half and concave posteriorly (Fig. 3E).

Metacarpals. The McIV NMB-AS79 (Fig. 3F-J) is short and rather gracile (GI = 23.0; Table 4), sagittally flattened, with a short insertion for the $m$. interossei on the medial side (Fig. 3I). It bears a salient insertion of the $m$. extensor carpalis on the anterior side (Fig. 3F), and a high and acute median keel of the distal articulation. In proximal view, the proximal facet is trapezoidal (Fig. 3J) and the articulation facet for the $\mathrm{McV}$ on the lateral side is not preserved (Fig. 3G).

\section{Remarks}

Based on comparison with coeval rhinocerotid genera, the referred specimens point to a remarkably small rhinoceros, excluding its assignation to the teleoceratine Diaceratherium.

Moreover, this genus differs by a developed external groove and a rounded trigonid on the whole lower cheek tooth series. The specimens differ from the acerathere (sensu lato) Mesaceratherium Heissig, 1969 by the absence of a lingual bridge between the protocone and the hypocone of the upper premolars, the absence of continuous lingual cingulum on P2-4, by a straight posterior part 
239 of the ectoloph on M1-2, as well as an oblique hypolophid on lower cheek teeth and a trapezoidal 240 outline of the proximal facet of the McIV (Heissig 1969, Bonis 1973, Antoine et al. 2010). The 241 material from Wischberg differs from Protaceratherium minutum (Cuvier, 1822) by a less

242 angular and V-shaped external groove on lower cheek teeth, as well as the lack of a labial and

243 continuous lingual cingulum, the absence of crochet and crista on upper premolars, and a shorter 244 and stouter McIV (Roman 1924).

245 The specimens share with the genus Pleuroceros some morphological similarities, such as a 246 reduced lingual cingulum on upper premolars, the absence of antecrochet on P2-3 and a straight 247 posterior part of the ectoloph on M1-2 (Antoine et al. 2010). The referred specimens differ from 248 Pleuroceros blanfordi (Lydekker 1884) by ca. 15\% smaller size, the absence of a lingual bridge 249 on P2-4 (semimolariform upper premolars, sensu Heissig 1969), a posteriorly directed metaloph

250

251

252

253

254

255

256

257

258

259

260

261

262

263

264

265

266

267

268

269

270

271

272

273

274

275

276

277

and a hypocone as strong as the protocone on P2, a protocone not constricted on P3-4, the absence of antecrochet on P4, the absence of mesostyle on M2, the metaconid not constricted on lower cheek teeth, and a reduced lingual cingulum on lower premolars (Antoine et al. 2010). The dimensions as well as the postcranial, cranial and dental morphology of Wischberg specimens are in fact extremely similar to the type material and other specimens of Pleuroceros pleuroceros (Duvernoy, 1853) from Gannat (type locality, collection MNHN), notably by the shape of the jugal bearing a processus postorbitalis, the molariform upper premolars lacking antecrochet, the only slightly constricted protoloph on M1-2, the typically convex ectometaloph of M3, the absence of antecrochet and protocone constriction on the M3, the reduction of the labial cingulum, the rather smooth external groove and rounded trigonid on lower cheek teeth and a somewhat short and gracile McIV (Duvernoy 1953, Bonis 1973, Antoine et al. 2010, pers. obs.; Table 4).

Genus Diaceratherium Dietrich, 1931

Original diagnosis (Dietrich, 1931; translation by the authors): "Medium-sized rhinoceros with pneumatised cranial bones; with long, thin and unfused nasal bones; onset of formation of a terminal horn. Four-fingered hand. Mesatipody. Brachyodont. Anterior dentition with large I1/i2. Molars homodont, simple, poorly folded. Decidual dentition: long lasting DI1DI2—DP14/di1di2 - dp1-4. Permanent dentition: I1—P2-4 M1-3/i2—p2-4 m1-3. Enamel slightly wrinkled, mostly vertically rugged."

Emended diagnosis: Medium-sized mediportal rhinoceros with long, thin and unfused nasal bones that can bear a small terminal horn. U-shaped nasal notch with a posterior border above P3 and straight occipital crest in dorsal view (not visible on the type material of $D$. tomerdingense). Anterior dentition with large I1/i2. Decidual dentition: DI1DI2-DP1-4/di1di2-dp1-4. Permanent dentition: I1—P2-4 M1-3/i2—p2-4 m1-3. Upper premolars semi-molariform to molariform with strong lingual cingulum. Upper molars without crista, but with a crochet, 
278 antecrochet and reduced lingual cingulum. Enamel slightly wrinkled, mostly vertically rugged.

279 Four-fingered hand.

280

281 Type species: Diaceratherium tomerdingense Dietrich, 1931

282 Included species: Diaceratherium lemanense (Pomel, 1853), Diaceratherium aurelianense

283 (Nouel, 1866), Diaceratherium asphaltense (Depéret and Douxami, 1902), Diaceratherium

284 aginense (Répelin, 1917), Diaceratherium lamilloquense Michel in Brunet et al., 1987,

285 Diaceratherium askazansorense Kordikova, 2001

286

287 Diaceratherium lemanense (Pomel, 1853)

288 Fig. 4-7, Table 5-10

289

290

291

Emended diagnosis: Based on comparisons with the material from type localities: Gannat for $D$. lemanense (MNHN collection and Boada-Saña et al. 2007, Boada-Saña 2008), La Milloque for

292

293 D. lamilloquense (Michel 1983), Pyrimont-Challonges for D. asphaltense (UCBL collection),

294 Laugnac for $D$. aginense (MHNM and UCBL collection), Neuville-aux-Bois for $D$. aurelianense 295 (Kordikova 2001).

296 Diaceratherium lemanense differs from $D$. tomerdingense by a larger size, the presence of a

297

298

299

300

301

302

303

304

305

306

307

308

309

310

311

312

313

314

315

316

317 posterolingual groove on the protocone of $\mathrm{P} 3-4$, a high, elongated and narrow anterior side of the semilunate, the symmetrical proximal border of the trapezoid in anterior view, the presence of a trapezium-facet and a large posterior McIII-facet on the McII, and a band-shaped magnum-facet on the McII. However, the large contact between the McV-facet and the pyramidal-facet of the unciform was believed to be a diagnostic character of $D$. lemanense, but it is also present in $D$. tomerdingense.

It differs from $D$. lamilloquense by the absence of a lingual bridge between the protocone and the hypocone of the upper premolars, a protoloph of $\mathrm{P} 2$ more transverse and connected to the ectoloph, the more reduced lingual cingulum on the upper molars and the pentagonal proximal facet of the McIV in proximal view

It differs from $D$. asphaltense by the absence of a lingual bridge between the protocone and the hypocone of P2-3, shorter nasals, occipital condyles about 20 to $25 \%$ wider, a magnum with a curved and not straight posterior tuberosity, a high, elongated and narrow anterior side of the semilunate, a band-shaped magnum-facet on the McII, a pentagonal proximal facet of the McIV in proximal view, the presence of an articulation facet for the tibia on the calcaneus and an elongated tuber calcanei in posterior view, and an acute median keels of the distal articulation of the metapodials.

It differs from $D$. aginense by a square $\mathrm{P} 2$ with a protoloph as long as the metaloph, the absence of metacone fold on P3-4, the absence of anterior groove on the protoloph of P3-4, the absence of lingual bridge between the protocone and the hypocone on P2-4, the strong and continuous lingual cingulum on upper premolars, the symmetrical distal articulation of the pyramidal for the 
318 semilunate, the greater posterior height of the scaphoid compared to its anterior height, the 319 contact between the $\mathrm{McV}$-facet and the pyramidal-facet of the unciform, a pentagonal proximal 320 facet of the McIV in proximal view and the slender tuber calcanei in posterior view of the 321 calcaneus.

322 It differs from $D$. aurelianense by the absence of a postorbital process of the frontals, the more 323 widely separated protocone and hypocone on $\mathrm{P} 2$, the stronger and continuous lingual cingulum 324 on P2-4, the absence of anterior groove on the protoloph of P3-4, the absence of lingual

325 cingulum in the openings of the valleys of the lower molars, the contact between the McV-facet 326

327 and the pyramidal-facet of the unciform, the much longer and more gracile metapodials, the absence of a fibula-facet on the calcaneum and the slender tuber calcanei in posterior view, the

328 higher and narrower astragalus as well as the shorter collum tali and a more concave $\mathrm{Cc} 1$ facet. Finally, it differs from $D$. askazansorense by a higher and narrower astragal with a much shorter

330

331

332

333

334

335

336

337

338

339

340

341

342

343

344

345

346

347

348

349

350

351

352

353

354

355

356

357

collum tali and a longer and more slender tuber calcanei.

Stratigraphical range: Latest Oligocene (MP30) to Early Miocene (MN2), Western Europe

(Antoine \& Becker 2013)

Occurrences: See Table 11.

Referred material: Skull with left M1-M3 (original exposed in ML, cast NMBE5031538, cast

NMB-AS75), right maxillary fragment with P3-M3 (NMBE5031539), right and left I1

(NMBE5031540), dental fragments of right I1 (NMBE5031546), left i2 (NMBE5031547), right P1 (NMBE5031548), left P3 (NMBE5031549), right P3 (NMBE5031550), two left lower cheek teeth (NMBE5031551 and NMBE5031552), right hemi-mandible with i2 and p2-m3 (NMBE5026738, cast NMB-UM6719), reconstructed incomplete mandible with left and right dental series with $\mathrm{p} 2-\mathrm{m} 3$ (original specimen exposed in ML, cast NMBE5031541, cast NMBAS76), right femur (NMBE5031542, cast NMB-UM6314), incomplete right tibia (NMBE5031543), right tibia (NMBE5031544, cast NMB-UM6315), right calcaneus (NMBE5031545), two right astragali (NMB-2017 and NMB-698), right MtII (NMBE5026812), right MtIII (NMBE5026811) from Wischberg (Switzerland, MN1)

\section{Figure 4:}

Diaceratherium lemanense (Perissodactyla, Rhinocerotidae) from Wischberg locality, Bern Canton, Swiss Molasse basin (MN1, Agenian, earliest Miocene).

Skull NMBE5031538 in laterodorsal (A), ventral (B) and occipital (C) views. Right hemimandible NMBE5026738 in labial (D), lingual (E) and occlusal (F) views with an enlarged occlusal view of the teeth (G). Right maxillary fragment NMBE5031539 in labial (H), lingual (I) and occlusal (J) views with an enlarged occlusal view of the teeth (K). Photo credit: Patrick Röschli.

\section{Figure 5:}

Diaceratherium lemanense (Perissodactyla, Rhinocerotidae) from Wischberg locality, Bern Canton, Swiss Molasse basin (MN1, Agenian, earliest Miocene). 
358

359

360

361

362

363

364

365

366

367

368

369

370

371

372

373

374

375

376

377

378

379

380

381

382

383

384

385

386

387

388

389

390

391

392

393

394

395

396

Left I1 NMBE5031540 in occlusal (A), lingual (B) and labial (C) views. Right I1 NMBE5031546 in occlusal (D), lingual (E) and labial (F) views. Right I1 NMBE5031540 in occlusal (G), lingual (H) and labial (I) views. Left i2 NMBE5031547 in occlusal (J), lingual $(K)$ and labial (L) views. Left P3 NMBE5031549 in occlusal (M) and lingual (N) views. Right $P 3$ NMBE5031550 in occlusal $(O)$ and lingual $(P)$ views. Fragmentary right $P 1$ NMBE5031548 in occlusal $(Q)$, lingual $(R)$ and labial $(S)$ views. Fragmentary left $p 4$ NMBE5031551 in occlusal (T), lingual (U) and labial (V) views. Photo credit: Patrick Röschli.

Figure 6:

Diaceratherium lemanense (Perissodactyla, Rhinocerotidae) from Wischberg locality, Bern Canton, Swiss Molasse basin (MN1, Agenian, earliest Miocene).

Right femur NMB-UM6314 in anterior (A), medial (B), posterior (C) and lateral (D) views. Right tibia NMBE5031544 in anterior (E), medial (F), posterior (G) and lateral (H) views. Photo credit: Patrick Röschli.

Figure 7:

Diaceratherium lemanense (Perissodactyla, Rhinocerotidae) from Wischberg locality, Bern Canton, Swiss Molasse basin (MN1, Agenian, earliest Miocene).

Right astragalus NMB-2017 in anterior (A) posterior (B) and distal (C) views. Right astragalus NMB-698 in anterior (D) posterior (E) and distal (F) views. Right calcaneus NMBE5031545 in distal (G), anterior $(\mathrm{H})$, lateral $(\mathrm{I})$, posterior $(\mathrm{J})$ and medial $(\mathrm{K})$ views. Right MtIII NMBE5026811 in anterior (L), lateral (M), posterior (N), medial (O) and proximal with dorsal toward top (P) views. Right MtII NMBE5026812 in proximal with dorsal toward top $(\mathrm{Q})$, anterior $(\mathrm{R})$, lateral $(\mathrm{S})$, posterior $(\mathrm{T})$ and medial $(\mathrm{U})$ views. Photo credit: Patrick Röschli.

Table 5:

Dimensions [mm] of the anterior teeth of Diaceratherium lemanense (Perissodactyla, Rhinocerotidae) from Wischberg locality, Bern Canton, Swiss Molasse basin (MN1, Agenian, earliest Miocene).

Table 6:

Dimensions [mm] of the upper cheek teeth of Diaceratherium lemanense (Perissodactyla, Rhinocerotidae) from Wischberg locality, Bern Canton, Swiss Molasse basin (MN1, Agenian, earliest Miocene).

Dimensions in parentheses are estimated.

Table 7: 
400

401

402

403

404

405

406

407

408

409

410

411

412

413

414

415

416

417

418

419

420

421

422

423

424

425

426

427

428

429

430

431

432

433

434

435

436

Dimensions [mm] of the lower cheek teeth of Diaceratherium lemanense (Perissodactyla, Rhinocerotidae) from Wischberg locality, Bern Canton, Swiss Molasse basin (MN1, Agenian, earliest Miocene).

\section{Table 8:}

Dimensions [mm] of the femur and tibia of Diaceratherium lemanense (Perissodactyla, Rhinocerotidae) from Wischberg and comparisons with other Diaceratherium and Pleuroceros specimens.

Dimensions in parentheses are estimated and those in italics are based on the literature. Localities are indicated below the taxon name and those in bold font are the type localities of the species. The upper line indicates the minimum and maximum dimensions, and the bottom line (when several specimen are used) indicates the average value and the number of specimens (in brackets).

\section{Table 9:}

Dimensions [mm] of the astragalus and calcaneum of Diaceratherium lemanense (Perissodactyla, Rhinocerotidae) from Wischberg and comparisons with other Diaceratherium and Pleuroceros specimens.

Dimensions in parentheses are estimated and those in italics are based on the literature. Localities are indicated below the taxon name and those in bold font are the type localities of the species. The upper line indicates the minimum and maximum dimensions, and the bottom line (when several specimen are used) indicates the average value and the number of specimens (in brackets).

\section{Table 10:}

Dimensions [mm] of the MtII and MtIII of Diaceratherium lemanense (Perissodactyla, Rhinocerotidae) from Wischberg and comparisons with other Diaceratherium and Pleuroceros specimens.

Dimensions in parentheses are estimated and those in italics are based on the literature. Localities are indicated below the taxon name and those in bold font are the type localities of the species. The upper line indicates the minimum and maximum dimensions, and the bottom line (when several specimen are used) indicates the average value and the number of specimens (in brackets).

\section{Table 11:}

Occurrences of Diaceratherium (Perissodactyla, Rhinocerotidae) species in France, Switzerland and other countries. Modified from Becker et al. (2009) with additions from Duranthon (1990, 1991), Antoine et al. (1997), Boada-Saña et al. (2007), Mennecart et al. (2012), Antoine \& Becker (2013) and Becker et al. (2018). Names in bold font indicate the type locality of the species. 
438

439

440

441

442

443

444

445

446

447

448

449

450

451

452

453

454

455

456

457

458

459

460

461

462

463

464

465

466

467

468

469

470

471

472

473

474

475

476

\section{Description}

Skull. The skull NMBE5031538 (Fig. 4A-C) is long and relatively narrow (Lcondyles-nasals = $575.5 \mathrm{~mm}$, Lcondyles-premaxilla $=615.5 \mathrm{~mm}$, Wfrontals $=158.5 \mathrm{~mm}$ ), belonging to a largesized adult rhinocerotid. It is incomplete and laterally compressed. It lacks the zygomatic arches, the occipital crest, as well as the anterior dentition and the right cheek tooth series, while only M1-3 are preserved in the left one. The dental remains are much worn, indicating an aged individual. The separated nasal bones are long, but less than the premaxilla, relatively thin, and bear a lateral apophysis (Fig. 4A). Roughness for a small nasal horn is preserved at the tip of the nasals. In lateral view, the foramen infraorbitalis and the posterior border of the U-shaped nasal notch are both located above the P3, while the anterior border of the orbit is above the M1/2 limit. The minimum distance between the posterior edge of the nasal notch and the anterior border of the orbit is $82.5 \mathrm{~mm}$. The back of the cheek teeth reaches the posterior half of the skull. The processus lacrymalis seems to be slightly developed and the processus postorbitalis of the frontal is absent. The base of the processus zygomaticus maxillari is high; it is about $2.5 \mathrm{~cm}$ above the neck of M2. The general dorsal profile of the skull is slightly concave, characterised by a nasal tip pointing downwards and by a slight posterior elevation of the parietal bones. In dorsal view, the postorbital constriction is very moderate, and the fronto-parietal crests are wellseparated. The processus postglenoidalis is long, strong and transversally narrow. The articular surface of the latter defines a right dihedron in cross section. The processus postglenoidalis is curved forward and contacts the short processus-posttympanicus, partially closing the external auditory pseudomeatus. The processus paraoccipitalis is long and well developed (Fig. 4C). The foramen magnum is circular. A smooth median transverse ridge runs all over the occipital condyles, but there is no axial truncation.

Mandible. The hemi-mandible NMBE5026738 (Fig. 4D-F) bears a very weak median sagittal groove (sulcus mylohyoideus) on the lingual side of the corpus mandibulae (Fig. 4E). The symphysis is thick and not constricted at the diastema level in the preserved side (Fig. 4F). It is upraised about $30^{\circ}$ with respect to the corpus mandibulae, and its posterior border, as well as the foramen mentale, is located below $\mathrm{p} 2$. The corpus mandibulae displays a straight ventral border with a constant height below p2-p4 (height below p2 $=80.3 \mathrm{~mm}$ ) that gets slightly higher until $\mathrm{m} 3$ (height below $\mathrm{m} 3=92.5 \mathrm{~mm}$ ). The incisura vasorum is weakly marked, the angulus mandibulae not much developed and the retromolar space rather long. The foramen mandibulae (Fig. 4E) is located below the alveolar level. The other referred mandibular specimen (casts NMBE5031541 and NMB-AS76) is greatly reconstructed and the anterior part of the symphysis is missing. The ramus mandibulae (maximum height $=250.0 \mathrm{~mm}$ ) is inclined forward, with a processus coronoideus sagittally well developed. The foramen mandibulae is also located much below the jugal teeth neck line.

Anterior teeth. The anterior dentition is reduced to the chisel-tusk shearing complex of I1-i2, characteristic of the family Rhinocerotidae sensu Radinsky (1966). The referred I1 are almondshaped in cross section (Fig. 5A-I) and the i2 is tusk-like (Fig. 5J-L). 
477 Upper cheek teeth. The cheek teeth are low-crowned (brachydont) and their roots are partly

478 joined. There is neither cement nor secondary enamel foldings on the crowns of cheek teeth. The 479 enamel is thin and wrinkled. Due to the advanced dental wear and the fragmented state of upper 480 cheek teeth, only few characters can be identified. The protocone of upper molars and premolars 481 is not constricted. The lingual and labial cingula are completely lacking on upper molars (Fig. 482 4B, H-K), while the lingual one seems to be strong and continuous on P3 (NMBE5031549 and NMBE5031550, Fig. 5M-P). The P1 NMBE5031548 is biradiculate and does not bear labial cingulum (Fig. 5Q-S). The P3 is molariform (sensu Heissig, 1969), the paracone fold seems poorly developed on upper molars and the M3 is quadrangular in occlusal view (Fig. 4B, K), with a transverse protoloph and a posterior groove on the ectometaloph.

Lower cheek teeth. The lower dental formula is $1 \mathrm{i}-3 \mathrm{p}-3 \mathrm{~m}$ (there are neither alveoli nor any trace of contact with the $\mathrm{d} 1 / \mathrm{p} 1$ on $\mathrm{p} 2$ ). The lower premolars are not reduced compared with the molars (Lp3-4/Lm1-3 > 50; Fig. 4D-G; Table 7). The lingual cingulum of the lower cheek teeth is reduced to the base of the opening of the anterior valley as an extension of the anterior cingulum (Fig. 4E). The labial cingulum is only present at the base of the paraconid, while the posterior is only present on lower premolars (Fig. 4D). The external groove is developed, oblique and vanishes before the neck. The trigonid is angular on lesser worn teeth and forms an acute dihedron with a rather developed lingual branch of the paralophid in occlusal view (Fig. 4G).

The talonid valley is narrow and V-shaped on $\mathrm{p} 2-\mathrm{m} 3$. The $\mathrm{p} 2$ displays a developed paraconid and a constricted paralophid (spur-like), an open posterior valley, as well as marked anterior and external grooves of the ectolophid. The hypolophid is transverse on lower molars and the entoconid of the lower molars does not bear a lingual groove.

Femur. The femur (NMBE5031542, Fig. 6A-D) is quite slender (Table 8) and anteroposteriorly compressed by deformation (Fig. 6B, D). The trochanter major is high, the articular facet of the head is slightly medially asymmetric, the fovea capitis is high and narrow, and the third trochanter is developed. In medial view (Fig. 6B), the anterior border of the diaphysis forms a slope break with the medial lip of the patellar trochlea. In anterior view (Fig. 6A), the distolateral epicondyle is low and well developed, the proximal border of the patellar trochlea is horizontal. The lateral lip is acute, while the lateral one is rounded.

Tibia. Two tibiae are preserved: the specimen NMBE5031544 is complete (Fig. 6E-H), well preserved and anteroposteriorly compressed by deformation, while the other (NMBE5031543) is incomplete. In distal view, the anterodistal groove is well marked. The mediodistal gutter for the m. tibialis is present and shallow, and the posterior apophysis is high and rounded (Fig. 6G). In lateral view (Fig. $6 \mathrm{H}$ ), the proximal articulation for the fibula is low and the diaphysis bears discontinuous contact marks for the fibula.

Astragalus. Two astragali are preserved (Fig. 7A-F). They slightly differ by their dimensions, but they are proportionally and morphologically homogeneous (Table 9). The fibula-facet is subvertical and transversely flat (Fig. 7A, D). The collum tali is high. In proximal view, the posteroproximal border of the trochlea is sinuous. In distal view (Fig 6C, F), the trochlea is very oblique compared to the distal articulation and the posterior stop on the cuboid-facet is present 
517 on NMB-2017 (not observable in NMB-698). The lateral lip is very prominent (Fig. 7A, D), and 518 the medial tubercle is low, salient, and laterally displaced. The calcaneus-facet 1 (sensu Heissig 519 1972) is very concave. The laterodistal expansion of this facet is broken, but was probably short 520 (Fig. 7B, E). The calcaneus-facet 2 is roughly oval, flat and wider than high. The calcaneus-facet 5213 is transversely developed and separated from the calcaneus-facet 2 by a notch (Fig. 7B, E).

522 Calcaneum. The calcaneum NMBE5031545 (TDmax =-, APDmax $=65.5 \mathrm{~mm}, \mathrm{H}=124.4 \mathrm{~mm}$;

523 Fig. 7G-K) is incomplete, the sustentaculum tali is not preserved. Both fibular and tibial facets 524 are lacking. The tuber calcanei is high and slender in distal view (Fig. 7G). The insertion for the 525 m. fibularis longus is marked on the lateral side (Fig. 7I), forming a deep notch. The corpus 526 calcanei is long (APD = 51.5) and narrow ( $\mathrm{TD}=27.2)$. The cuboid-facet forms a transverse half527 circle in distal view, and it is slightly convex anteroposteriorly.

528 Metatarsals. The metatarsals have a long insertion for the m. interossei (Fig. 7M, O and S), a 529 salient insertion for the m. extensor carpalis (Fig. 7L, R), and a high and acute median keel of 530 the distal articulation. The MtII bears a narrow and sagittally-elongated proximal end (Fig. 7Q). 531 The mesocuneiform facet forms a half oval. An axially elongated posteromedial entocuneiform532 facet joins the proximal facet (Fig. 7T). On the lateral side (Fig. 7S), the posterior ectocuneiform 533 facet is large and lozenge-shaped while the anterior one is smaller and nearly vertical. They are 534 separated by a large groove. The anterior and posterior MtIII-facets are poorly developed and 535 connected to the anterior and posterior ectocuneiform facets, respectively. The cuboid-facet of 536 the MtIII NMBE5026811 is absent. In proximal view (Fig. 7P), the anterior border of the MtIII 537 is slightly curved, while it is concave and high laterally, in anterior view (Fig. 7L). The MtIV538 facets are independent (Fig. 7M), the posterior one is distally displaced with respect to the 539 anterior one. The diaphysis slightly widens distally, reaching its maximal width immediately 540 above the distal articulation, especially due to the epicondyles. No posterodistal tubercle is 541 present on the diaphysis (Fig. 7N). The MtIII NMBE5026811 is rather robust (GI = 30.8; Table 542 10), while the MtII NMBE5026812 is shorter and more slender (GI = 24.6; Table 10).

543

544

545

\section{Remarks}

546

Based on dimensions and morphology, the referred specimens cannot be assigned to the smallsized contemporaneous European rhinocerotids. They differ from Protaceratherium minutum by larger dimensions, a thick mandibular symphysis, a reduced labial and lingual cingulum on lower cheek teeth, an astragalus wider than high and the separation between $\mathrm{Cc} 1$ and $\mathrm{Cc} 2$ facets (Bonis 1973, Ginsburg et al. 1981). They also differ from Pleuroceros pleuroceros by larger dimensions, as well as a developed external groove on lower cheek teeth, a reduced lingual cingulum on lower premolars, a subvertical fibula facet of the astragalus and an MtIII with a curved and oblique proximal border in anterior view (Bonis 1973, Antoine et al. 2010). Plesiaceratherium Young, 1937 and Mesaceratherium are roughly of similar size. The referred material differs from Plesiaceratherium by a developed ectolophid groove on lower cheek teeth, the absence of external roughnesses on $\mathrm{p} 2-3$, an ascending ramus of the mandible not inclined backwards, and much stouter metapodials (Yan and Heissig 1986, pers. obs.). It differs from 
557 Mesaceratherium by a less strongly raised symphysis, an astragalus wider than high and an

558

559

560

561

562

563

564

565

566

567

568

569

570

571

572

573

574

575

576

577

578

579

580

581

582

583

584

585

586

587

588

589

590

591

592

593

594

595

596

anteroposteriorly reduced proximal facet of the MtIII (Heissig 1969, Bonis 1973).

The assignment of the referred specimens to the genus Diaceratherium is supported by their dimensions and morphology. The nasals (long, thin and totally separated), the deep, U-shaped notch ending above P3, the orbital features (presence of a processus lacrymalis, anterior border above M1/2), the mandible (straight profile of the base of the corpus mandibulae), the dental remains (quadrangular M3, constricted paralophid and developed paraconid on $\mathrm{p} 2$ ) and the astragali (lateral lip larger than the medial one and a low, salient, and laterally displaced medial tubercle) present the characteristics of the genus Diaceratherium (Becker et al. 2009, 2010, 2018, Antoine et al. 2010, pers. obs.). However, the attribution of the studied material to a species within this genus remains difficult. Apart from "Diaceratherium” massiliae Ménouret and Guérin, 2009, whose generic attribution remains doubtful by several non-Diaceratherium morphological features (Antoine \& Becker 2013), between five and seven species of this genus are usually considered as valid in the literature (e.g. Heissig 1999, Boada-Saña et al. 2007, Becker et al. 2009, Antoine \& Becker 2013).

The studied material differs from the type species Diaceratherium tomerdingense by the absence of lingual cingulum under the protocone and at the opening of the median valley on M1-2, as well as an oblique external groove of lower premolars in labial view that does not vanish before the neck (Dietrich 1931, pers. obs.). Furthermore, though the metatarsals cannot be directly compared to the metacarpals from Tomerdingen, they would be much longer, because the metacarpals of $D$. tomerdingense are close to those of $D$. aginense from Laugnac, whose metatarsals are shorter than those from Wischberg (Table 4). However, the nasal bones are rather similar in size and shape, and also bear a small rugosity for the horn.

The specimens from Wischberg differ from the latest Oligocene diacerathere, D. lamilloquense, from La Milloque by the absence of lingual cingulum under the protocone of M3, a less angular trigonid on lower cheek teeth, and a low proximal articulation for the fibula on the tibia (Michel 1983, Brunet et al. 1987). They differ from the specimens from Castelmaurou by the absence of labial cingulum in the external groove of $\mathrm{m} 2$ and $\mathrm{m} 3$, and the absence of a posterior facet for the MtII on the MtIII (Duranthon 1990).

The skull NMBE5031538 and mandible NMBE5026738 differ from the type material of $D$. asphaltense from Pyrimont in having slightly stouter and shorter nasals, a moderate postorbital constriction of the skull, more distant frontoparietal crests, as well as a higher corpus of the mandible and a lower position of the foramen mandibulae on the ramus (Depéret and Douxami 1902, pers. obs.). Concerning the postcranial remains, some differences can be noted with $D$. asphaltense from Pyrimont and Saulcet, such as an anteroposteriorly reduced proximal facet of the MtIII for the ectocuneiform, a laterally compressed distal facet of the calcaneus for the cuboid and a slender tuber calcanei (Depéret and Douxami 1902, pers. obs.). The material from Wischberg differs from Diaceratherium aginense from Laugnac (type locality) in displaying a partially closed external auditory pseudomeatus, a less developed ectolophid groove of lower cheek teeth, a weaker lingual groove on the corpus mandibulae, a

Peer) reviewing PDF | (2019:05:37621:1:1:NEW 9 Jul 2019) 
597 longer posterodistal apophysis of the tibia, more gracile metapodials and a straighter navicular 598 facet of the astragalus in anterior view (Répelin 1917, pers. obs.).

599 It differs from Diaceratherium aurelianense by the absence of labial cingulum on lower molars, 600 the absence of the postorbital process of the frontals, the weaker lesser trochanter of the femur 601 and the more gracile and longer metapodials, with an acute median keel in distal view (Mayet 602 1908, Cerdeño 1993, pers obs.).

603 Finally, it differs from the Early Miocene Kazakh species Diaceratherium askazansorense by a 604 smaller size of the lower molars, a constant height of the horizontal ramus, less hypsodont teeth, 605 a lower collum tali of the astragalus and a slender tuber calcanei (Kordikova 2001).

606 The cranio-dental and postcranial characters of the diacerathere from Wischberg are in fact 607 morphologically indistinguishable from those of $D$. lemanense from Gannat (type locality). The 608 nasals are small, and same sized as the type skull from Gannat. Like the specimen from Gannat 609 NMB Gn. 40, the proximal facet of the MtIII is sagitally elongated and concave in anterior view. 610 The astragalus from this same individual is very similar to the two specimens from Wischberg 611 and is also wider than high. As in D. lemanense from Montaigu (NMB S.G.18480), the ramus 612 mandibulae is inclined forward, with a sagittally well developed processus coronoideus. The 613 lingual and labial cingula are also absent on lower cheek teeth. The material from Wischberg 614 only differs by a slightly smaller size than the type material. Therefore, we attribute the referred 615 specimens from Wischberg to D. lemanense.

616

\section{Discussion}

\section{Systematic remarks}

619 The systematics of the genus Diaceratherium is far from consensual. Four species in particular

620

621

622

623

624

625

626

627

628

629

630

631

632

633

634

635

636 are contentious and often subject to synonymies: D. lemanense, D. asphaltense, $D$. tomerdingense and D. aginense. After Antoine \& Becker (2013) and Becker et al. (2018), D. tomerdingense is a junior synonym of $D$. aginense and the latter is likely to be a junior synonym of $D$. asphaltense. More recently, Becker et al. (2018) still accepted the synonymy of $D$. tomerdingense and $D$. aginense, but maintained $D$. asphaltense as valid whereas, according to Bonis (1973) and Boada-Saña et al. (2007), D. asphaltense and D. tomerdingense should be considered as junior synonyms of $D$. lemanense. However, no clear justification is ever provided, except for the synonymy of $D$. asphaltense and D. lemanense by the phylogenetic analysis of Boada-Saña (2008). Yet, the coding of $D$. asphaltense in this work is based on photographs of the type material from Pyrimont-Challonges (Boada-Saña, 2008: tab. 1). As a matter of fact, based on direct examination of the type material of $D$. lemanense, $D$. asphaltense, $D$. aginense and $D$. tomerdingense, we conclude that these four species can be differentiated based on their morphology, and can be considered as valid, as expressed in the emended diagnosis of $D$. lemanense.

These synonymies probably derived from the absence of differential diagnoses between these four species, and of designated type for D. lemanense. Indeed, a skull referred to 
637 "Acerotherium" lemanense from the type locality of Gannat (Roman 1912, P1. VIII fig. 1-3) was 638 unfortunately mistakenly considered as a reference specimen for comparison by Becker et al. 639 (2009, 2018) whereas Boada-Saña (2007) had designated another skull and mandible from 640 Gannat (MNHN AC 2375 and MNHN AC 2376 respectively) as lectotype. Regrettably, both 641 skulls from Gannat may belong to two different taxa, which led to unfortunate comparisons of 642 specimens and erroneous taxonomic attributions. The skull used by Becker et al. $(2009,2018)$ as 643 reference material of $D$. lemanense (FSL-213944) is remarkably similar to the skull attributed to 644 D. lemanense from Eschenbach (NMSG-P2006/1), but after direct observation could both be 645 referred to Plesiaceratherium. Moreover, cranial remains from Saulcet (NMB-SAU-1662) and 646 Bühler (NMSG-F13607) have been referred to D. asphaltense (Becker et al. 2009, 2018), based 647 on similarities with the type skull of $D$. asphaltense from Pyrimont-Challonges (FSL-

648 212997bis), but also on indisputable dissimilarities with the non-Diaceratherium skulls from 649 Gannat (FSL-213944) and Eschenbach (NMSG-P2006/1).

650 Finally, another systematic interpretation has been recently proposed by Heissig (2017), who 651 referred the species $D$. aurelianense to the genus Prosantorhinus because of characters not found 652 in other species of the genus Diaceratherium. These characters are "the deeply concave skull 653 profile with upslanting nasals, a wide nasal incision of medium depth, and the triangular last 654 upper molar." Similarities between the two genera had already been expressed by Cerdeño 655 (1996) who referred some specimens previously attributed to D. aurelianense to the genus 656 Prosantorhinus but keeping both taxa as valid. Antoine et al. (2018) have also recently attributed 657 all the material previously referred as Diaceratherium aurelianense from Béon 2 to 658 Prosantorhinus aff. douvillei, which indicates indeed similarities between these two taxa, as also 659 already noted by Mayet (1908). However, Antoine et al. (2018) subsequently expressed 660 numerous anatomical differences between these two taxa, including the $20 \%$ size difference of 661 the MtIV, which is a character that specifically distinguishes these two genera. Moreover, the 662 characters used by Heissig (2017) seem quite labile to confirm the attribution of the species $D$. 663 aurelianense to the genus Prosantorhinus. Indeed, a recently described skull of Diaceratherium 664 asphaltense from Bühler does show a deeply concave skull and slightly upslanted nasals (Becker 665 et al. 2018), though not as much as the skull of $D$. aurelianense (Fig. 8). Another skull of $D$. 666 asphaltense from Saulcet has a similar morphology, but it is true that D. lemanense and $D$. 667 aginense do not show such an upslanted nasal bone (though for the latter species the skulls 668 illustrated by Répelin (1917) are heavily reconstructed, and the global shape is very misleading). 669 Finally, the M3 is indeed more triangular in D. aurelianense than in other species of the genus,

670 but it could be a character specific to this species. Therefore, to the best of our knowledge, the 671 four above-mentioned problematic Diaceratherium species should be considered as valid, just as

672 D. lamilloquense and D. askazansorense, and D. aurelianense should still belong to the genus

673 Diaceratherium (as presented in Table 11).

674

675 Figure 8:

676 Comparison of the skulls of Diaceratherium (Perissodactyla, Rhinocerotidae). 
677 (A) D. asphaltense (NMSG-F13607) from Bühler (MP30-MN1; Becker et al. 2018). (B) D.

678

679

680

681

682

683

684

685

686

687

688

689

690

691

692

693

694

695

696

697

698

699

700

701

702

703

704

705

706

707

708

709

710

711

712

713

714

715

716

apshaltense (NMB Sau 1662) from Saulcet (MN1). (C) D. aurelianense (MHNT.PAL.2013.0.1001, cast of the holotype) from Neuville-aux-Bois (MN3). (D) $D$. aginense (FSL collection) from Laugnac (MN2). (E) D. lemanense (MNHN-AC-2375, holotype) from Gannat (MN1). (F) D. lemanense (cast NMBE5031538) from Wischberg (MN1).

\section{Palaeoecology and diversification}

The Agenian rhinocerotid fauna from Wischberg includes two co-occurring mediportal species: the large-sized single-horned Diaceratherium lemanense, and the small-sized tandem-horned Pleuroceros pleuroceros. The two taxa also differ by their body masses (Table 12), the former being a megaherbivorous with a body mass estimated to be over $10^{3} \mathrm{~kg}$ (Owen-Smith 1988). The record of Pleuroceros pleuroceros and Diaceratherium lemanense is typical from the MN1 biozone, Gannat (France) being the type locality of both taxa, and is comparable to some contemporaneous French localities such as Paulhiac, Pyrimont-Challonges and Saulcet. This sympatric association is characteristic of the MN1 biozone and results from the faunal renewal starting at MP28 in Western Europe (Scherler et al. 2013). The presence of Diaceratherium lemanense in Wischberg extends the record of this genus in Switzerland. Indeed, though the species D. lemanense was found in numerous French localities, Wischberg is the only record of this species in Switzerland during the MN1 biozone (Table 11). The genus Diaceratherium has a rather long record in Europe, from the late Oligocene to the early middle Miocene, and it survives the Oligocene-Miocene transition and diversifies then, with the presence of four different species during MN1: D. tomerdingense (type species), D. lemanense, D. asphaltense and D. aginense. In addition, Diaceratherium and Pleuroceros are also found in Asia at the same period: Pleuroceros blanfordi in Pakistan (Antoine et al. 2010) and Diaceratherium askazansorense in Kazakhstan (Kordikova 2001), which could indicate rhinocerotid exchanges between Europe and Asia.

\section{Table 12:}

Estimates of rhinocerotid species body mass from Wischberg locality, Bern Canton, Swiss Molasse basin (MN1, Agenian, earliest Miocene).

Based on the allometric correlations with the occlusal surface of the first lower molar (Legendre, 1989), the transverse width of the tibial trochlea of the astragalus (Li1; Tsubamoto, 2014) and various femoral and tibial measurements (Fortelius \& Kappelman, 1993).

The Agenian period is marked by the beginning of a major worldwide diversification phase of Rhinocerotidae that lasted until the Late Miocene (Cerdeño 1998), and during which perissodactyls reached the maximum body size and mass among terrestrial mammals (Smith et al. 2010). This rhinocerotid diversification may be due to the extinction of other 
717 megaherbivorous competitors in Europe such as the Anthracotheriinae (latest Oligocene,

718 Scherler 2011, Scherler et al. 2018) or the Amynodontidae (Late Oligocene, Malez \& Thenius, 719 1985). As for the other European perissodactyls, except for the Tapiridae, which are present in 720 Europe until MN4, Palaeotheriidae are extinct since MP25 (Rémy 1995), Chalicotheriidae only 721 re-appear during MN2 (Coombs 2009), Equidae first appear with Anchitherium in MN3 (Kaiser 722 2009, Alberdi \& Rodríguez 2012) and Eggysodontidae disappear in MN1 (Scherler et al. 2013). 723 However, none of those reached sizes over $10^{3} \mathrm{~kg}$ during this time. Within the Artiodactyla only 724 nine genera were present in Europe during MN1 (Scherler et al. 2013) and all of them were 725 smaller than the smallest rhinocerotids (Scherler 2011, Mennecart 2012). Finally, the

726 proboscideans, another group of megaherbivores that will later dominate the megaherbivore 727 communities, do not appear in Europe until mid-Orleanian times (MN3b; Antoine et al. 1997, 728 Göhlich 1999). As a result, the earliest Miocene is a period during which rhinocerotids are the 729 dominating largest herbivores and the only megaherbivores in Europe (Rössner \& Heissig 1999, 730 Scherler et al. 2013). This observation is of particular interest since, like extant African 731 megaherbivores, Early Miocene rhinocerotids likely had large food intake requirements and 732 could have been able to subsist on low-quality (i.e. high fibre) food resources (Demment \& van 733 Soest 1985, Owen-Smith 1988, Illius and Gordon 1992). Furthermore, due to their size, Early 734 Miocene megaherbivorous rhinocerotids are expected, like extant ones, to display specific life735 history attributes, physiology and ecological characteristics related to their body mass (Blueweiss 736 et al. 1978, Brown et al. 2004), such as larger geographic ranges, higher potential for dispersal

737 (e.g., Brown 1995, Gaston 2003), lower mortality rates and better resistance to limiting 738 environmental factors (Erb et al. 2001). As a result, megaherbivores are considered to be a 739 separate trophic guild among large herbivores (Fritz et al. 2002), possibly better adapted to 740 ecosystems with high plant biomass but low-quality vegetation (Bell 1982).

741 The beginning of the Miocene is marked by a short glacial event (Mi-1; Zachos et al. 2001). This

742 sudden climatic event induced significant changes in the European vegetation. We observe 743 indeed a lower proportion of C4 plants during the MN1 than during the Oligocene (Urban et al. 744 2010) and an increase of mesothermic vegetations at the expense of megathermic ones (e.g. 745 Mosbrugger et al. 2005, Bessedik et al. 1984) which may have promoted fibre-rich plants 746 associations at the beginning of the Miocene (e.g. Leguminosae; Berger 1990). Janis (1976) 747 hypothesised that perissodactyls (hindgut fermenters) were able to overcome competition of 748 other large herbivorous mammals, especially ruminants (foregut fermenters), by their ability to 749 tolerate more fibrous herbage. This could explain the diversification of rhinocerotids at the 750 beginning of the Miocene, for which large size and digestive system might have increased their 751 ability to monopolise resources (Fritz et al. 2002) and extract nutrients from specific feeding 752 niches (Illius \& Gordon 1992). The evolutionary success and rapid diversification of

753 rhinocerotids during the earliest Miocene could consequently be linked to this particular 754 environmental change, triggered by the short glaciation event but also by the absence of other 755 megaherbivores. After the late Oligocene faunal renewal (Scherler et al. 2013), the earliest 756 Miocene, and especially the first one million-year period (MN1), may have been a crucial time 
757 period for the Rhinocerotidae, and especially megaherbivorous taxa, to start diversifying by

758 occupying new ecological niches available at that time. Further analyses taking into account all

759 European rhinocerotids, with their masses and anatomical features, will be necessary to test this

760 hypothesis and better understand this unique transition in the European assemblages of

761 megaherbivores at the beginning of the Miocene.

762

763

764

765

766

767

768

769

770

771

772

773

774

775

776

777

778

779

780

781

782

783

784

785

786

787

788

789

790

\section{Conclusions}

Based on comparisons, the rhinocerotid specimens from Wischberg, a typical early Agenian (MN1) locality, can be attributed to two different taxa: Diaceratherium lemanense and Pleuroceros pleuroceros. Though Schaub \& Hürzeler (1948) had identified a third taxon, Diaceratherium asphaltense, we believe that the material identified as such should be attributed to the coeval $D$. lemanense, based on morphological differences with the holotype of $D$. asphaltense from Pyrimont-Challonges (MN1, France). Furthermore, we believe that all the species of Diaceratherium found at the present time in the literature could be considered as valid, until an extensive revision of this genus is performed, preferentially through a phylogenetic analysis.

\section{Acknowledgements}

We are greatly indebted to all curators of the collections visited during this work, who kindly helped us during our visit: Manuela Aiglstorfer and Reinhard Ziegler (SMNS), Christine Argot and Guillaume Billet (MNHN), Christophe Borrely (MHNM), Jana Fehrensen (ML), Yves Laurent (MHNT), Ursula Menkveld-Gfeller (NMBE), Emmanuel Robert (FSL) and especially Loïc Costeur (NMB) who kindly provided additional measurements. We thank Clara Stefen for her editorial work. Finally we would like to gratefully acknowledge Luca Pandolfi, Esperanza Cerdeño and Pierre-Olivier Antoine for their insightful reviews and comments, which helped us to greatly improve our draft.

\section{References}

Agustí, J., Cabrera, L., Garcés, M., Krijgsman, W., Oms, O., \& Parés, J. M. (2001). A calibrated mammals scale for the Neogene of Western Europe. State of the art. Earth-Science Reviews, 52, 247-260.

Alberdi, M. T., \& Rodríguez, J. (2012). Anchitherium Meyer, 1844 (Perissodactyla, Equidae) de Sansan. In Peigné S., Sen S. (eds), Mammifères de Sansan (pp. 487-533). Mémoires du Muséum National d'Histoire Naturelle, 203.

791 Antoine, P.-O. (2002). Phylogénie et évolution des Elasmotheriina (Mammalia, Rhinocerotidae).

792 Mémoires du Muséum national d'Histoire naturelle de Paris, 188, 1-359.

793 Antoine, P.-O., \& Becker, D. (2013). A brief review of Agenian rhinocerotids in Western

794 Europe. Swiss Journal of Geosciences, 106, 135-146.

795 Antoine, P.-O., Duranthon, F. \& Tassy, P., 1997. L'apport des grands mammifères

796 (Rhinocérotidés, Suoidés, Proboscidiens) à la connaissance des gisements du Miocène 
797 d'Aquitaine (France). In J.-P. Aguilar, S. Legendre \& J. Michaux (Eds.), Actes du Congrès

798 BiochroM'97 (pp. 581-590). Montpellier: Ecole pratique des hautes études-Sciences de la vie et 799 de la terre-Institut de Montpellier.

800 Antoine, P.-O., Downing, K. F., Crochet, J.-Y., Duranthon, F., Flynn, L. J., Marivaux, L.,

801 Métais, G., Rajpar A. R. \& Roohi, G. (2010). A revision of Aceratherium blanfordi Lydekker,

8021884 (Mammalia: Rhinocerotidae) from the Early Miocene of Pakistan: postcranials as a key.

803 Zoological Journal of the Linnean Society, 160, 139-194.

804 Antoine, P.-O., Becker, D., Laurent, Y., \& Duranthon, F. (2018) The Early Miocene

805 teleoceratine Prosantorhinus aff. douvillei (Mammalia, Perissodactyla, Rhinocerotidae) from

806 Béon 2, Southwestern France. Revue de Paléobiologie, 37, 367-377.

807 Becker, D. (2003). Paléoécologie et paléoclimats de la Molasse du Jura (Oligo-Miocène): apport

808 des Rhinocerotoidea (Mammalia) et des minéraux argileux. GeoFocus, 9, 1-327.

809 Becker, D., Rössner, G., Picot, L., \& Berger, J.-P. (2001). Early Miocene ruminants from

810 Wallenried (USM, Aquitanian/Switzerland): biostratigraphy and paleoecology. Eclogae

811 Geologicae Helveticae, 94, 547-564.

812 Becker, D., Bürgin, T., Oberli, U., \& Scherler, L. (2009). A juvenile skull of Diaceratherium

813 lemanense (Rhinocerotidae) from the Aquitanian of Eschenbach (eastern Switzerland). Neues

814 Jahrbuch für Geologie und Paläontologie Abhandlungen, 254, 5-39.

815 Becker, D., Antoine, P.-O., Engesser, B., Hiard, F., Hostettler, B., Menkveld-Gfeller, U.,

816 Mennecart, B., Scherler, L., \& Berger, J.-P. (2010). Late Aquitanian mammals from Engehalde

817 (Molasse Basin, Canton Bern, Switzerland). Annales de Paléontologie, 96, 95-116.

818 Becker, D., Antoine, P.-O., Mennecart, B., \& Tissier, J. (2018). New rhinocerotid remains in the

819 latest Oligocene-Early Miocene of the Swiss Molasse Basin. Revue de Paléobiologie, 37, 395-

820408.

821 Bell, R.H.V. (1982). The effect of soil nutrient availability on the community structure in African

822 ecosystems. In: Huntley, B.J. and Walker, B. H. (eds), pp. 193-216. Ecology of tropical

823 savannas, Springer.

824 Berger, J.-P. (1990). Le rôle des environnements de dépôt pour les reconstitutions climatiques:

825 les gisements à végétaux de la Molasse Grise de Lausanne (Miocène inférieur, Suisse

826 occidentale). Paléobiologie continentale, 17, 345-353.

827 Berger, J.-P. (2011). Du bassin molassique au fossé rhénan, évolution des paléoenvironnements

828 dans un avant pays dynamique. Géochroniques, Magazine des Géosciences, 117, 44-49

829 Berger, J.-P., Reichenbacher, B., Becker, D., Grimm, M., Grimm, K. I., Picot, L., Storni, A.,

830 Pirkenseer, C., Schäfer, H., \& Derer, C. (2005a). Paleogeography of the Swiss Molasse basin and 831 the URG from Late Eocene to Pliocene. International Journal of Earth Sciences, 94, 697-710.

832 Berger, J.-P., Reichenbacher, B., Becker, D., Grimm, M., Grimm, K.I., Picot, L., Storni, A., 833 Pirkenseer, C., \& Schäfer, A. (2005b). Eocene-Pliocene time scale and stratigraphy of the Upper

834 Rhine Graben (URG) and the Swiss Molasse Basin (SMB). International Journal of Earth

835 Sciences, 94, 711-731. 
836 Bessedik, M., Guinet, P. \& Suc, J.-P. (1984). Données paléofloristiques en méditerranée nord837 occidentale depuis l'Aquitanien. Revue de Paleobiologie, volume spécial : 25-31.

838 BiochroM'97 (1997). Synthèses et tableaux de corrélations. In J.-P. Aguilar, S. Legendre \& J. 839 Michaux (Eds.), Actes du Congrès BiochroM'97 (pp. 769-805). Montpellier: Ecole pratique des 840 hautes études-Sciences de la vie et de la terre-Institut de Montpellier.

841 Blueweiss, L., Fox, H., Kudzma, V., Nakashima, D., Peters, R. \& Sams, S. (1978). Relationships 842 between body size and some life history parameters. Oecologia, 37(2):257-272.

843 Boada-Saña, A. (2008). Phylogénie du rhinocérotidé Diaceratherium Dietrich, 1931 (Mammalia, 844 Perissodactyla). Master thesis dissertation (unpublished), University of Montpellier 2, France.

845 Boada-Saña, A., Hervet, S., \& Antoine, P.-O. (2007). Nouvelles données sur les rhinocéros

846 fossiles de Gannat (Allier, limite Oligocène-Miocène). Revue des Sciences Naturelles

847 d'Auvergne, 71, 1-25.

848 Bonis, L. de (1973). Contribution à l'étude des Mammifères de l'Aquitanien de l'Agenais:

849 rongeurs-carnivores-périssodactyles. Mémoires du Muséum national d'Histoire naturelle de 850 Paris, 28, 1-192.

851 Brown, J.H. (1995). Macroecology. The University of Chicago Press, Chicago.

852 Brown, J.H., Gillooly, J.F., Allen, A.P., Savage, V.M. \& West, G.B. (2004). Toward a metabolic 853 theory of ecology. Ecology, 85(7): 1771-1789.

854 Brunet, M., Bonis, L. de, \& Michel, P. (1987). Les grands Rhinocerotidae de l'Oligocène et du

855 Miocène inférieur d'Europe occidentale: intérêt biostratigraphique. Münchner

856 Geowissenschaftliche Abhandlungen, 10, 59-66.

857 Cerdeño, E. (1993). Étude sur Diaceratherium aurelianense et Brachypotherium brachypus

858 (Rhinocerotidae, Mammalia) du Miocène moyen de France. Bulletin du Muséum national

859 d'histoire naturelle de Paris, 15, 25-77.

860 Cerdeño, E. (1996). Prosantorhinus, the small teleoceratine rhinocerotid from the Miocene of

861 Western Europe. Geobios, 29, 111-124.

862 Cerdeño, E. (1998). Diversity and evolutionary trends of the Family Rhinocerotidae

863 (Perissodactyla). Palaeogeography, Palaeoclimatology, Palaeoecology, 141, 13-34.

864 Coombs, M. C. (2009). The chalicothere Metaschizotherium bavaricum (Perissodactyla, 865 Chalicotheriidae, Schizotheriinae) from the Miocene (MN5) Lagerstätte of Sandelzhausen

866 (Germany): description, comparison, and paleoecological significance. Paläontologische

867 Zeitschrift, 83, 85-129.

868 Cuvier, G. (1822). Recherches sur les ossements fossiles, où l'on rétablit les caractères de

869 plusieurs animaux dont les révolutions du globe ont détruit les espèces. 4ème édition, Paris, 10

870 vol.

871 Demment, M.W. \& van Soest, P.J. (1985). A nutritional explanation for body-size patterns of

872 ruminant and non ruminant herbivores. American Naturalist, 125: 641-672

873 Depéret, C., \& Douxami, H. (1902). Les Vertébrés oligocènes de Pyrimont-Challonges (Savoie).

874 Mémoires suisses de Paléontologie, 29, 1-92. 
875 Dietrich, W. O. (1931). Neue Nashornreste aus Schwaben (Diaceratherium tomerdingensis $\mathrm{n}$. $\mathrm{g}$. 876 n. sp.). Zeitschrift für Säugetierkunde, 6, 203-220.

877 Duranthon, F. (1990). Étude paléontologique (Rongeurs, Anthracothéridés, Rhinocérotidés) de

878 la molasse toulousaine (Oligo-miocène). Biostratigraphie et implications géodynamiques.

879 Diplôme EPHE, Montpellier (unpublished).

880 Duranthon, F. (1991). Biozonation des molasses continentales oligo-miocènes de la région

881 toulousaine par l'étude des mammifères. Apports à la connaissance du bassin d'Aquitaine

882 (France). Comptes Rendus de l'Académie des Sciences, 313 (Série II), 965-970.

883 Duvernoy, G. L. (1853). Nouvelles études sur les rhinocéros fossiles. Archives du Muséum

884 d'Histoire Naturelle, Paris, 7, 1-144.

885 Engesser, B. \& Mödden, C. (1997). A new version of the biozonation of the Lower Freshwater

886 Molasse (Oligocene and Agenian) of Switzerland and Savoy on the basis of fossil Mammals. In

887 J.-P. Aguilar, S. Legendre \& J. Michaux (Eds.), Actes du Congrès BiochroM’97 (pp. 475-499).

888 Montpellier: Ecole pratique des hautes études-Sciences de la vie et de la terre-Institut de

889 Montpellier.

890 Erb, J., Boyce, M.S. \& Stenseth, N.C. (2001). Population dynamics of large and small mammals.

891 Oikos, 92: 3-12

892 Fortelius, M. \& Kappelman, J. (1993). The largest land mammal ever imagined. Zoological

893 Journal of the Linnean Society, 107, 85-101.

894 Fritz, H., Duncan, P., Gordon, I.J. \& Illius, A.W., (2002). Megaherbivores influence trophic

895 guilds structure in African ungulates communities. Oecologia, 131: 620-625.

896 Gaston, K.J. (2003). The structure and dynamics of geographic ranges. Oxford University Press,

897 Oxford.

898 Ginsburg, L., \& Bulot, C. (2000). Le cadre stratigraphique du site de Sansan. Bulletin du

899 Muséum national d'histoire naturelle, 183, 39-67.

900 Ginsburg, L., Huin, J., \& Locher, J. P. (1981). Les Rhinocerotidae (Perissodactyla, Mammalia)

901 du Miocène inférieur des Beilleaux à Savigné-sur-Lathan (Indre-et-Loire). Bulletin du Muséum

902 National d'Histoire Naturelle de Paris, 3, 345-361.

903 Gerber, E. 1932. Über den Fund eines Rhinoceratiden aus der unteren Süsswassermolasse von

904 Langenthal und dessen stratigraphische Stellung. Eclogae Geologicae Helvetiae 25/2, 274-275.

905 Gerber, E. 1936. Über einen zweiten Rhinoceriden-Fund aus der unteren Süsswassermolasse von

906 Langenthal. Eclogae Geologicae Helvetiae 29/2, 580.

907 Göhlich, U.B. (1999). Order Proboscidea. In G. Rössner and K. Heissig (eds.), The Miocene

908 Land Mammals of Europe (pp. 157-168). München: Verlag Dr. Friedrich Pfeil.

909 Guérin, C. (1980). Les rhinocéros (Mammalia, Perissodactyla) du Miocène terminal au

910 Pléistocène supérieur en Europe occidentale. Comparaison avec les espèces actuelles. Documents

911 des Laboratoires de Géologie de Lyon, 79, 1184 pp.

912 Gray, J. E. (1821). On the natural arrangements of vertebrose animals. London Medical

913 Repository, 15, 296-310. 
914 Habicht, J. K. A. (1987). Lexique stratigraphique international. Volume I Europe. Fascicule 7:

915 Suisse. Fascicule 7b: Plateau suisse (Molasse). Commission Géologique Suisse et Service

916 Hydrogéologique et Géologique National, Birkhäuser AG, Reinach/Basel, 528 pp.

917 Heissig, K. (1969). Die Rhinocerotidae (Mammalia) aus der oberoligozänen Spaltenfüllung von

918 Gaimersheim bei Ingolstadt in Bayern und ihre phylogenetische Stellung. Abhandlungen der

919 Bayerische Akademie der Wissenschaften, Mathematisch-Naturwissenschaftliche Klasse, 138, 1-

920133.

921 Heissig K. (1972). Die obermiozäne Fossil-Lagerstätte Sandelzhausen. 5. Rhinocerotidae

922 (Mammalia), Systematik und Ökologie. Mitteilungen der Bayerischen Staatssammlung für

923 Paläontologie und historische Geologie, 12, 57-81.

924 Heissig K. (1999). Family Rhinocerotidae. In G. E. Rössner \& K. Heissig (Eds.), The Miocene

925 Land Mammals of Europe (pp. 175-188). München: Verlag Dr. Friedrich Pfeil.

926 Heissig, K. (2017). Revision of the European species of Prosantorhinus Heissig, 1974

927 (Mammalia, Perissodactyla, Rhinocerotidae). Fossil Imprint, https://doi.org/10.1515/if-2017-

$928 \quad 0014$

929 Hilgen, F. J., Lourense, L. J., \& Van Dam, J. A. (2012). The Neogene Period. In F. M. Gradstein, 930 J. G. Ogg, M. D. Schmitz \& G. M. Ogg (Eds.). The Geologic Time Scale 2012. Volume 2 (pp. 931 923-978). Oxford: Elsevier.

932 Hugueney, M. (1997). Biochronologie mammalienne dans le Paléogène et le Miocène inférieur

933 du centre de la France: Synthèse réactualisée. . In J.-P. Aguilar, S. Legendre \& J. Michaux

934 (Eds.), Actes du Congrès BiochroM'97 (pp. 417-430). Montpellier: Ecole pratique des hautes

935 études-Sciences de la vie et de la terre-Institut de Montpellier.

936 Illius, A.W. \& Gordon, I.J. (1992). Modelling the nutritional ecology of ungulate herbivores:

937 evolution of body size and competitive interactions. Oecologia, 89: 428-434.

938 Janis, C.M. (1976). The evolutionary strategy of the Equidae and the origins of rumen and cecal 939 digestion. Evolution, 30: 757-774.

940 Kaiser, T. M. (2009). Anchitherium aurelianense (Equidae, Mammalia): a brachydont "dirty

941 browser" in the community of herbivorous large mammals from Sandelzhausen (Miocene,

942 Germany). Paläontologische Zeitschrift, 83, 131-140.

943 Kempf, O., Bolliger, T., Kälin, D., Engesser, B., \& Matter, A. (1997). New magnetostratigraphic

944 calibration of Early to Middle Miocene mammal biozones of the north alpine foreland basin. In

945 J.-P. Aguilar, S. Legendre \& J. Michaux (Eds.), Actes du Congrès BiochroM'97 (pp. 547-561).

946 Montpellier: Ecole pratique des hautes études-Sciences de la vie et de la terre-Institut de

947 Montpellier.

948 Kempf, O., Matter, A., Burbank, D. W., \& Mange, M. (1999). Depositional and structural

949 evolution of a foreland basin margin in a magnetostratigraphic framework: the eastern Swiss

950 Molasse Basin. International Journal of Earth Sciences, 88, 253-275.

951 Kordikova, E. G. (2001). Remarks on the Oligocene-Miocene mammal paleontology and

952 sequence stratigraphy of South-Western Betpakdala Steppe, South Kazakhstan. Neues Jahrbuch

953 für Geologie und Paläontologie Abhandlungen, 221, 35-79. 
954 Lavocat, R. (1951). Révision de la faune des mammifères oligocènes d'Auvergne et du Velay.

955 Sciences et Avenir, Paris, $153 \mathrm{pp}$.

956 Legendre, S. (1989). Les communautés de mammifères du paléogène (Eocène supérieur et

957 Oligocène) d'Europe occidentale: structures, milieux et évolution. Münchner

958 Geowissenschaftliche Abhanlungen, 16: 1-110.

959 Linnaeus, C. (1758). Systema Naturae per regna tria naturae, secundum classes, ordines,

960 genera, species, cum characteribus, differentiis, synonymis, locis. Vol. 1: Regnum animale. 10th

961 edition, Stockholm.

962 Lydekker, R. (1884). Additional Siwalik Perissodactyla and Proboscidea. Memoirs of the

963 Geologcal Survey of India. Palaeontologia Indica, 3, 1-34.

964 Malez, M., \& Thenius, E. (1985). Über das Vorkommen von Amynodonten (Rhinocerotoidea,

965 Mammalia) im Oligo-Miozän von Bosnien (Jugoslawien). Palaeontologia Jugoslavica, 34, 1-26.

966 Mayet, L. (1908). Etude des Mammifères Miocènes des Sables de l'Orléanais et des Faluns de la

967 Touraine. Annales de l'Université de Lyon, Nouvelle Série, 24: 1-336.

968 Mein, P. (1999). European Miocene Mammal Biochronology. In G. E. Rössner \& K. Heissig

969 (Eds.), The Miocene Land Mammals of Europe (pp. 25-38). München: Verlag Dr. Friedrich Pfeil.

970 Mennecart, B. (2012). The Ruminantia (Mammalia, Cetartiodactyla) from the Oligocene to the

971 Early Miocene of Western Europe: systematics, palaeoecology and palaeobiogeography.

972 GeoFocus, 32, 1-263.

973 Mennecart, B., Scherler, L., Hiard, F., Becker, D., \& Berger, J. P. (2012). Large mammals from

974 Rickenbach (Switzerland, reference locality MP29, Late Oligocene): biostratigraphic and

975 palaeoenvironmental implications. Swiss Journal of Palaeontology, 131(1), 161-181.

976 Mennecart, B, Yerly, B, Mojon, P-O, Angelone, C, Maridet, O, Böhme, M, \& Pirkenseer, C.

977 (2016). A new Late Agenian (MN2a, Early Miocene) fossil assemblage from Wallenried

978 (Molasse Basin, Canton Fribourg, Switzerland). Paläontologische Zeitschrift, 90(1), 101-123.

979 Ménouret, B., \& Guérin, C. (2009). Diaceratherium massiliae nov. sp. des argiles oligocènes de

980 Saint-André et Saint-Henri à Marseille et de Les Milles près d'Aix-en-Provence (SE de la

981 France), premier grand Rhinocerotidae brachypode européen. Geobios, 42, 293-327.

982 Michel, P. (1983). Contribution à l'étude des Rhinocérotidés oligocènes (La Milloque; Thézels;

983 Puy de Vaurs). Thesis dissertation (unpublished). Université de Poitiers, France.

984 Mosbrugger, V., Utescher, T. \& Dilcher, D.L. (2005). Cenozoic continental climatic evolution of

985 Central Europe. Proceedings of the National Academy of Sciences of the United States of

986 America, 102: 14964-14969.

987 Nouel, E. (1866). Mémoire sur un nouveau rhinocéros fossile. Mémoires de la Société

988 d'Agriculture, Sciences, Belle-Lettres et Art d'Orléans, 8, 241-251 (1864-1866).

989 Owen, R. (1848). The archetype and homologies of the vertebrate skeleton. London: $203 \mathrm{pp}$.

990 Owen-Smith, R.N. (1988) Megaherbivores. The influence of very large body size on ecology.

991 Cambridge University Press, Cambridge. 
992 Pomel, M. (1853). Catalogue méthodologique et descriptif des vertébrés fossiles découverts dans

993 le bassin hydrographique supérieur de la Loire, et surtout dans la vallée de son affluent

994 principal, l'Allier. Paris: Baillière Ed.

995 Radinsky, L. B. (1966). The Families of the Rhinocerotoidea (Mammalia, Perissodactyla).

996 Journal of Mammalogy, 47 (4), 631-639.

997 Rémy, J. A. (1995). Le Garouillas et les sites contemporains (Oligocène, MP25) des

998 Phosphorites du Quercy (Lot, Tarn-et-Garonne, France) et leurs faunes de vertébrés. 8.

999 Périssodactyles: Palaeotheriidae. Palaeontographica Abteilung A, 236, 151-155.

1000 Répelin, J. (1917) Études paléontologiques dans le Sud-Ouest de la France (Mammifères). Les

1001 rhinocérotidés de 1'Aquitanien supérieur de l'Agenais (Laugnac). Annales du Musée d'Histoire

1002 Naturelle de Marseille, 16, 1-47.

1003 Roger, O. (1898). Wirbeltierreste aus dem Dinotheriensande der bayerisch-schwäbischen

1004 Hochebene. Bericht des Naturwissenschaftlichen Vereins für Schwaben, Neuburg, 33, 1-46,

1005 383-396.

1006 Roman, F. (1912). Les rhinocérotidés de l'Oligocène d'Europe. Archives du Musée des Sciences

1007 Naturelles de Lyon, 11, 1-92.

1008 Rössner, G. E., \& Heissig, K. (1999). The Miocene Land Mammals of Europe. München: Verlag 1009 Dr. Friedrich Pfeil.

1010 Schaub, S., \& Hürzeler, J. (1948). Die Saügertierefauna des Aquitanian von Wischberg bei

1011 Langenthal. Eclogae Geologicae Helvetiae, 41, 354-366.

1012 Scherler, L. (2011). Terrestrial paleoecosystems of large mammals (Tapiridae,

1013 Anthracotheriidae, Suoidea) from the Early Oligocene to the Early Miocene in the Swiss

1014 Molasse Basin: biostratigraphy, biogeochemistry, paleobiogeography, and paleoecology. Thesis

1015 dissertation (unpublished). University of Fribourg, Switzerland.

1016 Scherler, L., Becker, D., \& Berger, J.-P. (2011). Tapiridae (Perissodactyla, mammalia) of the

1017 Swiss Molasse Basin during the Oligocene-Miocene transition. Journal of Vertebrate

1018 Paleontology, 31, 479-496.

1019 Scherler, L., Lihoreau, F., \& Becker, D. (2018). To split or not to split Anthracotherium? A

1020 phylogeny of Anthracotheriinae (Cetartiodactyla: Hippopotamoidea) and its

1021 palaeobiogeographical implications. Zoological Journal of the Linnean Society, 185, 487-510.

1022 Scherler, L., Mennecart, B., Hiard, F., \& Becker, D. (2013). Evolutionary history of hoofed

1023 mammals during the Oligocene-Miocene transition in Western Europe. Swiss Journal of

1024 Geosciences, 106: 349-369.

1025 Schlosser, M. (1902). Beiträge zur Kenntnis der Säugetierreste aus den süddeutschen Bohnerzen.

1026 Geologische und Paläontologische Abhandlungen, Jena, N.F. 5: 117-258.

1027 Schweizerisches Komitee für Stratigraphie und Landesgeologie (2014). Unités

1028 lithostratigraphiques de la Suisse. Lexique lithostratigraphique de la Suisse (pp. 1-8).

1029 Bundesamt für Landestopographie swisstopo, Wabern.

1030 https://www.strati.ch/_Resources/Static/Packages/Swisstopo.Strati/docs/LithostratigraphischeEin

1031 heitenSchweiz.pdf.

PeerJ reviewing PDF | (2019:05:37621:1:1:NEW 9 Jul 2019) 
1032 Smith, F.A., Boyer, A.G., Brown, J.H., Costa, D.P., Dayan, T., Ernest, S.K.M., Evans, A.R., 1033 Fortelius, M., Gittleman, J.L., Hamilton, M.J., Harding, L.E., Lintulaakso, K., Lyons, S.K., 1034 McCain, C., Okie, J.G., Saarinen, J.J., Sibly, R.M., Stephens, P.R., Theodor, J. \& Uhen, M.D., 1035 2010. The Evolution of Maximum Body Size of Terrestrial Mammals. Science, 330: 1216-1219. 1036 https://doi.org/10.1126/science. 1194830

1037 Steininger, F. (1999). The Continental European Miocene. Chronostratigraphy, geochronology 1038 and biochronology of the Miocene "European Land Mammal Mega-Zones" (ELMMZ) and the 1039 Miocene "Mammal-Zones (MN-Zones)". In G. E. Rössner \& K. Heissig (Eds.), The Miocene 1040 Land Mammals of Europe (pp. 9-24). München: Verlag Dr. Friedrich Pfeil.

1041 Tobien, H. (1975). Zur Gebisstruktur, Systematik und Evolution der Genera Piezodus, Prolagus 1042 und Ptychoprolagus (Lagomorpha, Mammalia) aus einigen Vorkommen im jungeren Tertiar 1043 Mittel- und Westeuropas. Notizblatt des Hessischen Landesamtes für Bodenforschung zu 1044 Wiesbaden, 103, 103-186.

1045 Tsubamoto, T. (2014). Estimating body mass from the astragalus in mammals. Acta 1046 Palaeontologica Polonica, 59, 259-265.

1047 Urban, M.A., Nelson, D.M., Jimenez-Moreno, G., Chateauneuf, J.-J., Pearson, A. \& Hu, F.S. 1048 (2010). Isotopic evidence of $\mathrm{C}^{4}$ grasses in southwestern Europe during the Early Oligocene1049 Middle Miocene. Geology, 38: 1091-1094.

1050 Yan, D., \& Heissig, K. (1986). Revision and Autopodial Morphology of the Chinese-European 1051 Rhinocerotid Genus Plesiaceratherium Young 1937. Zitteliana Abhandlungen der Bayerische 1052 Staatssammlung für Paläontologie und historische Geologie, München, 14, 81-110.

1053 Young, C. C. (1937). On a Miocene mammalian fauna from Shantung. Bulletin of the Geological 1054 Society of China, 17, 209-244.

1055 Zachos, J.C., Shackleton, N.J., Revenaugh, J.S., Pälike, H. \& Flower, B.P. (2001). Climate 1056 response to orbital forcing across the Oligocene-Miocene boundary. Science, 292: 274-278. 


\section{Table $\mathbf{1}$ (on next page)}

Mammal assemblage of Wischberg locality, Bern Canton, Swiss Molasse basin (MN1, Agenian, earliest Miocene). 


\begin{tabular}{ll}
\hline After Schaub \& Hürzeler & $\begin{array}{l}\text { After Tobien (1975), Scherler et al. (2013) } \\
\text { (1948) }\end{array}$ \\
\hline Talpidarum indet. & Talpidae indet. \\
Erinaceus priscus & Amphechinus edwardsi \\
Lagomorphum aff. piezodus & Piezodus tomerdingensis \\
Cricetodon cf. hochheimensis & Eucricetodon cf. hochheimensis \\
Cricetodon collatus & Eucricetodon collatus \\
Plesiosminthus myarion & Plesiosminthus myarion \\
Rhodanomys schlosseri & Rhodanomys schlosseri \\
Rhodanomys sp. nov. & Rhodanomys sp. nov. \\
Eomyidarum gen. nov. & Ritteneria sp. \\
Gliridarum gen. nov. & Gliridae indet. \\
Cainotherium laticurvatum & Cainotherium latircurvatum \\
Elomeryx minor & Elomeryx minor \\
Palaeochoerus meissneri & Hyotherium meissneri \\
Amphitragulus sp. & Amphitragulus elegans \\
Tapirus intermedius var. & Eotapirus broennimanni (adult specimens) \\
robustus & \\
Tapirus brönnimanni & Eotapirus broennimanni (juvenile specimens) \\
Aceratherium lemanense & Diaceratherium lemanense \\
Diceratherium asphaltense & Diaceratherium lemanense \\
Diceratherium pleuroceros & Pleuroceros pleuroceros \\
&
\end{tabular}




\section{Table 2 (on next page)}

Dimensions [mm] of the cheek teeth of Pleuroceros pleuroceros (Perissodactyla, Rhinocerotidae) from Wischberg locality, Bern Canton, Swiss Molasse basin (MN1, Agenian, earliest Miocene).

Dimensions in parentheses are estimated. 


\begin{tabular}{|c|c|c|c|c|c|c|c|}
\hline \multicolumn{4}{|c|}{$\begin{array}{l}\text { Pleuroceros pleuroceros } \\
\text { casts NMBE5031553 and NMB-AS77 }\end{array}$} & \multicolumn{4}{|c|}{ casts NMBE5026739 and NMB-AS78 } \\
\hline $\begin{array}{l}\text { Upper } \\
\text { tooth }\end{array}$ & $\mathrm{L}_{\mathrm{P} 3-4}$ & $\mathrm{~L}_{\mathrm{M} 1-3}$ & $\mathrm{~L}_{\mathrm{P} 3-4} / \mathrm{L}_{\mathrm{M} 1-3} \times 100$ & $\begin{array}{l}\text { Lower } \\
\text { tooth }\end{array}$ & $\mathrm{L}_{\mathrm{p} 3-4}$ & $\mathrm{~L}_{\mathrm{m} 1-3}$ & $\mathrm{~L}_{\mathrm{p} 3-4} / \mathrm{L}_{\mathrm{m} 1-3} \times 100$ \\
\hline row & & & & row & & & \\
\hline left & 53.5 & 94.0 & 56.9 & & & & \\
\hline right & 54.0 & 95.0 & 56.8 & right & - & 101.5 & - \\
\hline $\begin{array}{l}\text { Upper } \\
\text { cheek } \\
\text { teeth }\end{array}$ & $\mathrm{L}$ & $\mathrm{W}$ & $\mathrm{H}$ & $\begin{array}{l}\text { Lower } \\
\text { cheek } \\
\text { teeth }\end{array}$ & $\mathrm{L}$ & $\mathrm{W}$ & $\mathrm{H}$ \\
\hline right $\mathrm{P} 1$ & 15.1 & 15.1 & - & & & & \\
\hline left P2 & 23.2 & 26.8 & - & & & & \\
\hline right $\mathrm{P} 2$ & 24.0 & 27.1 & - & & & & \\
\hline left P3 & 25.7 & 34.6 & - & & & & \\
\hline right $\mathrm{P} 3$ & 27.8 & 36.6 & - & & & & \\
\hline left P4 & 27.8 & 37.8 & - & & & & \\
\hline right $\mathrm{P} 4$ & 27.1 & 37.2 & - & right $\mathrm{p} 4$ & 28.0 & 19.9 & \\
\hline left M1 & 31.8 & 38.1 & - & left $\mathrm{m} 1$ & 30.5 & 18.2 & \\
\hline right $\mathrm{M} 1$ & 31.0 & 35.8 & - & right m1 & 29.0 & $(19.0)$ & \\
\hline left M2 & 37.5 & 40.3 & 20.2 & left $\mathrm{m} 2$ & 34.5 & 21.3 & \\
\hline right $\mathrm{M} 2$ & 39.0 & 41.3 & 19.1 & right $\mathrm{m} 2$ & 33.6 & 21.0 & \\
\hline left M3 & 32.0 & 37.5 & 23.7 & & & & \\
\hline right $\mathrm{M} 3$ & 33.8 & 38.3 & - & right $\mathrm{m} 3$ & 36.9 & 20.8 & \\
\hline
\end{tabular}




\section{Table 3 (on next page)}

Dimensions [mm] of the semilunate of Pleuroceros pleuroceros from Wischberg (NMBE5031537) and comparison with other specimens of Pleuroceros and Diaceratherium.

Dimensions in parentheses are estimated and those in italics are based on the literature. Localities are indicated below the taxon name and those in bold font are the type localities of the species. The upper line indicates the minimum and maximum dimensions, and the bottom line (when several specimen are used) indicates the average value and the number of specimens (in brackets). 


\begin{tabular}{llll}
\hline Semilunate & TD & APD & H \\
\hline $\begin{array}{l}\text { P. pleuroceros } \\
\text { Wischberg (this study) }\end{array}$ & 30.6 & 53.2 & 38.8 \\
\hline $\begin{array}{l}\text { P. pleuroceros } \\
\text { Paulhiac (Bonis 1973) }\end{array}$ & $(34.5)$ & $(45.0)$ & $(34.5)$ \\
\hline $\begin{array}{l}\text { P. blandfordi } \\
\text { Bugti Hills (Antoine et al. 2010) }\end{array}$ & 34.0 & 55.0 & 36.0 \\
\hline $\begin{array}{l}\text { D. lamilloquense } \\
\text { Castelmaurou (Duranthon 1990) }\end{array}$ & 43.8 & 52.5 & 47.5 \\
$\begin{array}{l}\text { D. asphaltense } \\
\text { Pyrimont-Challonges (Type, }\end{array}$ & 44.8 & 59.5 & 43.1 \\
coll. UCBL) & & & \\
\hline $\begin{array}{l}\text { D. asphaltense } \\
\text { Saulcet (coll. NMB) }\end{array}$ & $47.0-47.0$ & $67.0-67.3$ & $51.0-51.5$ \\
\hline $\begin{array}{l}\text { D. aginense } \\
\text { Laugnac (coll. MHNM) }\end{array}$ & $38.0-44.4$ & $60.7-65.0$ & $45.6-51.5$ \\
\hline $\begin{array}{l}\text { D. aurelianense } \\
\text { Artenay (Cerdeño 1993) }\end{array}$ & $40.7[8]$ & $62.1[6]$ & $48.4[8]$ \\
\hline
\end{tabular}

1 


\section{Table 4 (on next page)}

Dimensions [mm] of the McIV of Pleuroceros pleuroceros from Wischberg (NMB AS79) and comparison with Diaceratherium species (Perissodactyla, Rhinocerotidae).

Dimensions in parentheses are estimated and those in italics are based on the literature. Localities are indicated below the taxon name and those in bold font are the type localities of the species. The upper line indicates the minimum and maximum dimensions, and the bottom line (when several specimen are used) indicates the average value and the number of specimens (in brackets). 


\begin{tabular}{llllllll}
\hline McIV & L & $\begin{array}{l}\text { TD } \\
\text { prox }\end{array}$ & $\begin{array}{l}\text { APD } \\
\text { prox }\end{array}$ & $\begin{array}{l}\text { TD } \\
\text { dia }\end{array}$ & $\begin{array}{l}\text { APD } \\
\text { dia }\end{array}$ & $\begin{array}{l}\text { TD } \\
\text { dist }\end{array}$ & $\begin{array}{l}\text { APD } \\
\text { dist }\end{array}$ \\
\hline $\begin{array}{l}\text { P. pleuroceros } \\
\text { Wischberg (this study) }\end{array}$ & 112.3 & 32.6 & 31.1 & 26.0 & 15.2 & - & 28.8 \\
\hline $\begin{array}{l}\text { D. lemanense } \\
\text { Gannat (coll. NMB) }\end{array}$ & 132.5 & 47.0 & 39.0 & 33.0 & 19.5 & 43.5 & 40.5 \\
\hline $\begin{array}{l}P \text {. pleuroceros } \\
\text { Paulhiac (Bonis 1973) }\end{array}$ & $(112.5)$ & $(28.5)$ & $(31.5)$ & $(27.0)$ & $(16.0)$ & $(36.5)$ & $(27.0)$ \\
\hline $\begin{array}{l}\text { D. lamilloquense } \\
\text { La Milloque (Michel 1983) }\end{array}$ & 116.0 & 26.0 & - & 28.0 & - & $(30.5)$ & - \\
\hline $\begin{array}{l}\text { D. lamilloquense } \\
\text { Castelmaurou (Duranthon 1990) }\end{array}$ & 125.3 & $37.4-38.0$ & $40.2-41.2$ & $32.2-33.3$ & $19.9-20.5$ & 43.6 & 37.0 \\
\hline $\begin{array}{l}\text { D. tomerdingense } \\
\text { Tom }\end{array}$ & 116.3 & $47.7[2]$ & $40.7[2]$ & $32.3[2]$ & $20.2[2]$ & & 39.3
\end{tabular}

Tomerdingen (Type, coll.

SMNS)

\begin{tabular}{|c|c|c|c|c|c|c|c|}
\hline D. asphaltense & $117.0-122.0$ & $40.0-40.5$ & $38.5-39.0$ & $29.5-30.0$ & $19.0-19.5$ & $39.0-41.0$ & $34.5-35.0$ \\
\hline $\begin{array}{l}\text { Pyrimont-Challonges (Type, } \\
\text { coll. UCBL) }\end{array}$ & $119.5[2]$ & $40.3[2]$ & $38.8[2]$ & $29.8[2]$ & $19.3[2]$ & $40.0[2]$ & $34.8[2]$ \\
\hline $\begin{array}{l}\text { D. asphaltense } \\
\text { Saulcet (coll. NMB) }\end{array}$ & 124.0 & 34.7 & 39.5 & 32.2 & 21.6 & 38.5 & 34.2 \\
\hline D. aginense & $112.2-120.4$ & $39.5-40.8$ & $43.3-43.6$ & $27.3-29.6$ & $17.3-17.9$ & $38.7-40.4$ & $36.0-38.0$ \\
\hline Laugnac (coll. MHNM) & $117.4[4]$ & $40.2[2]$ & $43.5[2]$ & $28.1[4]$ & $17.7[4]$ & $39.5[3]$ & $37.2[4]$ \\
\hline $\begin{array}{l}\text { D. aurelianense } \\
\text { Neuville-aux-Bois (Cerdeño } \\
\text { 1993) }\end{array}$ & 106.0 & 42.0 & 44.6 & 29.5 & 18.5 & 43.8 & 40.3 \\
\hline
\end{tabular}




\section{Table 5 (on next page)}

Dimensions [mm] of the anterior teeth of Diaceratherium lemanense (Perissodactyla, Rhinocerotidae) from Wischberg locality, Bern Canton, Swiss Molasse basin (MN1, Agenian, earliest Miocene). 


\begin{tabular}{|c|c|c|c|c|c|c|c|}
\hline \multicolumn{8}{|c|}{ Diaceratherium lemanense } \\
\hline $\begin{array}{l}\text { Upper incisors } \\
\text { (I1) }\end{array}$ & APD & $\mathrm{TD}$ & $\mathrm{H}$ & Lower incisors (i2) & APD & TD & $\mathrm{H}$ \\
\hline $\begin{array}{l}\text { NMBE5031540 } \\
\text { (left) }\end{array}$ & 50.2 & 18.5 & 18.2 & $\begin{array}{l}\text { NMBE5031547 } \\
\text { (left) }\end{array}$ & - & - & 43.0 \\
\hline $\begin{array}{l}\text { NMBE5031540 } \\
\text { (right) }\end{array}$ & - & 17.5 & 17.1 & $\begin{array}{l}\text { NMBE5026738 } \\
\text { (right) }\end{array}$ & 31.9 & 24.0 & 41.2 \\
\hline $\begin{array}{l}\text { NMBE5031546 } \\
\text { (right) }\end{array}$ & - & 17 & 16.0 & & & & \\
\hline
\end{tabular}

1 


\section{Table 6(on next page)}

Dimensions [mm] of the upper cheek teeth of Diaceratherium lemanense (Perissodactyla, Rhinocerotidae) from Wischberg locality, Bern Canton, Swiss Molasse basin (MN1, Agenian, earliest Miocene).

Dimensions in parentheses are estimated. 


\begin{tabular}{|c|c|c|c|}
\hline $\begin{array}{l}\text { Diaceratherium le } \\
\text { Original NMBE50 }\end{array}$ & MBE503 & nd NM & \\
\hline Upper tooth row & $\mathrm{L}_{\mathrm{P} 3-4}$ & $\mathrm{~L}_{\mathrm{M} 1-3}$ & $\mathrm{~L}_{\mathrm{P} 3-4} / \mathrm{L}_{\mathrm{M} 1-3} \times 100$ \\
\hline right & $(68.0)$ & 126.9 & $(53.6)$ \\
\hline Upper cheek teeth & $\mathrm{L}$ & $\mathrm{W}$ & \\
\hline right $\mathrm{P} 4$ & $(34.5)$ & $(42.6)$ & \\
\hline left M1 & 39.2 & - & \\
\hline right M1 & 39.7 & 47.0 & \\
\hline left M2 & 47.1 & 51.1 & \\
\hline right $\mathrm{M} 2$ & 44.0 & 50.5 & \\
\hline left M3 & 48.0 & 52.6 & \\
\hline right $\mathrm{M} 3$ & 46.1 & - & \\
\hline
\end{tabular}




\section{Table 7 (on next page)}

Dimensions [mm] of the lower cheek teeth of Diaceratherium lemanense (Perissodactyla, Rhinocerotidae) from Wischberg locality, Bern Canton, Swiss Molasse basin (MN1, Agenian, earliest Miocene). 


\begin{tabular}{|c|c|c|c|c|c|c|c|}
\hline \multicolumn{4}{|c|}{$\begin{array}{l}\text { Diaceratherium lemanense } \\
\text { NMBE5026738 }\end{array}$} & \multicolumn{4}{|c|}{ casts NMBE5031541 and NMB-AS76 } \\
\hline $\begin{array}{l}\text { Lower } \\
\text { tooth } \\
\text { row }\end{array}$ & $\mathrm{L}_{\mathrm{p} 3-4}$ & $\mathrm{~L}_{\mathrm{m} 1-3}$ & $\mathrm{~L}_{\mathrm{p} 3-4} / \mathrm{L}_{\mathrm{m} 1-3} \times 100$ & $\begin{array}{l}\text { Lower } \\
\text { tooth } \\
\text { row }\end{array}$ & $\mathrm{L}_{\mathrm{p} 3-4}$ & $\mathrm{~L}_{\mathrm{m} 1-3}$ & $\mathrm{~L}_{\mathrm{p} 3-4} / \mathrm{L}_{\mathrm{m} 1-3} \times 100$ \\
\hline right & 78.0 & 137.0 & 56.9 & $\begin{array}{l}\text { left } \\
\text { right }\end{array}$ & $\begin{array}{l}77.0 \\
76.5 \\
\end{array}$ & $\begin{array}{l}130.0 \\
133.5\end{array}$ & $\begin{array}{l}59.2 \\
57.3 \\
\end{array}$ \\
\hline $\begin{array}{l}\text { Lower } \\
\text { cheek } \\
\text { teeth }\end{array}$ & $\mathrm{L}$ & $\mathrm{W}$ & & $\begin{array}{l}\text { Lower } \\
\text { cheek } \\
\text { teeth }\end{array}$ & $\mathrm{L}$ & $\mathrm{W}$ & $\mathrm{H}$ \\
\hline right $\mathrm{p} 2$ & 30.0 & 20.1 & & $\begin{array}{l}\text { left } \mathrm{p} 2 \\
\text { right } \mathrm{p} 2\end{array}$ & $\begin{array}{l}28.5 \\
28.0\end{array}$ & $\begin{array}{l}- \\
16.9\end{array}$ & $\begin{array}{l}24.2 \\
26.9\end{array}$ \\
\hline right p3 & 36.0 & 25.0 & & $\begin{array}{l}\text { left } \mathrm{p} 3 \\
\text { right p3 }\end{array}$ & $\begin{array}{l}38.2 \\
36.1\end{array}$ & $\begin{array}{l}22.1 \\
24.0\end{array}$ & - \\
\hline right p4 & 40.5 & 29.5 & & $\begin{array}{l}\text { left } \mathrm{p} 4 \\
\text { right } \mathrm{p} 4\end{array}$ & $\begin{array}{l}36.5 \\
38.5\end{array}$ & $\begin{array}{l}29.0 \\
26.5\end{array}$ & - \\
\hline right $\mathrm{m} 1$ & 42.8 & 28.5 & & $\begin{array}{l}\text { left } \mathrm{m} 1 \\
\text { right } \mathrm{m} 1\end{array}$ & $\begin{array}{l}39.5 \\
40.5\end{array}$ & $\begin{array}{l}28.7 \\
26.5\end{array}$ & - \\
\hline right $\mathrm{m} 2$ & 46.0 & 30.5 & & $\begin{array}{l}\text { left } \mathrm{m} 2 \\
\text { right } \mathrm{m} 2\end{array}$ & $\begin{array}{l}44.2 \\
46.8\end{array}$ & $\begin{array}{l}30.5 \\
29.8\end{array}$ & $\begin{array}{l}27.5 \\
28.0\end{array}$ \\
\hline right $\mathrm{m} 3$ & 49.5 & 28.5 & & left $\mathrm{m} 3$ & 47.5 & 28.5 & 31.0 \\
\hline
\end{tabular}




\section{Table 8(on next page)}

Dimensions [mm] of the femur and tibia of Diaceratherium lemanense (Perissodactyla, Rhinocerotidae) from Wischberg and comparisons with other Diaceratherium and Pleuroceros specimens.

Dimensions in parentheses are estimated and those in italics are based on the literature. Localities are indicated below the taxon name and those in bold font are the type localities of the species. The upper line indicates the minimum and maximum dimensions, and the bottom line (when several specimen are used) indicates the average value and the number of specimens (in brackets). 


\begin{tabular}{lllllll}
\hline Long bones & L & TD & APD & TD & APD & TD \\
& & prox & prox & dia & dia & dist \\
\hline
\end{tabular}

Femur

\begin{tabular}{llllllll}
\hline D. lemanense & 499.0 & 187.5 & 69.0 & 66.0 & 55.0 & 132.0 & 130.5
\end{tabular}

Wischberg (this study)

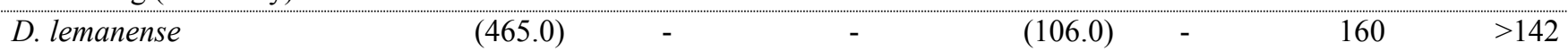

Gannat (Type, coll. MNHN)

D. lamilloquense
Castelmaurou (Duranthon 1990)

D. tomerdingense

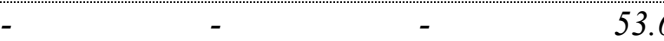

$\begin{array}{llll}53.6 & 49.0 & - & 120.0\end{array}$

Tomerdingen (Type, coll.

SMNS)

D. asphaltense

429.0

168.0

63.0

117.0

Pyrimont-Challonges (Type,

Depéret \& Douxami 1902)

$\begin{array}{lllllll}\text { D. aginense } & 490.0 & 165.0 & 90.0 & 61.6 & 52.0 & 125.0\end{array}$

Laugnac (coll. MHNM)

D. aurelianense

433.0

161.0

84.9

59.0

43.5

$129.0 \quad 140.0$

Neuville-aux-Bois (Cerdeno

1993)

Tibia

D. lemanense

380

124.5

84.4

65.0

40.5

93.8

48.3

Wischberg (this study)

D. lemanense

381

132

99

56

103

Gannat (Type, coll. MNHN)

P. blandfordi

Bugti Hills (Antoine et al. 2010

D. lamilloquense

$-\quad-$

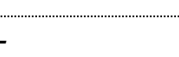

La Milloque (Michel 1983)

D. lamilloquense

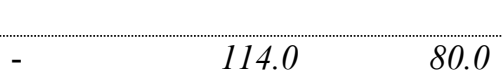

$\begin{array}{llll}47.0-47.0 & 33.5-36.0 & 73-78.5 & (50.0)-57.5\end{array}$

Castelmaurou (Duranthon 1990)

D. tomerdingense 337.0

109.0

77.5 $34.5[3]$

$76.1[4] \quad 52.9[4]$

Tomerdingen (Type, coll.

SMNS)

D. asphaltense

(351.0)

111.0

45.0

90.0

Pyrimont-Challonges (Type,

Depéret \& Douxami 1902)

D. asphaltense

Saulcet (coll. NMB)

D. aginense

Laugnac (coll. MHNM)

D. aurelianense

Neuville-aux-Bois (Cerdeño

1993)

\begin{tabular}{lllllll}
361.0 & 123.8 & 109.5 & 56.0 & 46.5 & 98.6 & 64.0 \\
\hline $322.0-360.0$ & $113.0-128.0$ & $95.5-102.0$ & $45.3-49.9$ & $39.6-48.6$ & $87.2-92.1$ & $55.5-61.9$ \\
$338.0[4]$ & $120.5[3]$ & $98.4[4]$ & $48.3[4]$ & $43.9[4]$ & $89.0[4]$ & $60.0[4]$ \\
$274.0-288.0$ & $102.0-112.0$ & 104.0 & $46.0-51.0$ & $40.3-47.0$ & 94.4 & $60.0-68.2$ \\
$281.0[2]$ & $107.0[2]$ & & $48.5[2]$ & $43.7[2]$ & & $64.1[2]$
\end{tabular}




\section{Table 9 (on next page)}

Dimensions [mm] of the astragalus and calcaneum of Diaceratherium lemanense (Perissodactyla, Rhinocerotidae) from Wischberg and comparisons with other Diaceratherium and Pleuroceros specimens.

Dimensions in parentheses are estimated and those in italics are based on the literature. Localities are indicated below the taxon name and those in bold font are the type localities of the species. The upper line indicates the minimum and maximum dimensions, and the bottom line (when several specimen are used) indicates the average value and the number of specimens (in brackets). 


\begin{tabular}{|c|c|c|c|}
\hline Tarsals & TD & APD & $\mathbf{H}$ \\
\hline \multicolumn{4}{|l|}{ Astragal } \\
\hline D. lemanense & $76.8-85.5$ & $40.0-41.5$ & $70.5-74.0$ \\
\hline Wischberg (this study) & 81.2 [2] & $40.8[2]$ & $72.3[2]$ \\
\hline D. lemanense & 87.1 & 65.0 & 70.3 \\
\hline \multicolumn{4}{|l|}{ Gannat (coll. NMB) } \\
\hline \multicolumn{4}{|l|}{ Paulhiac (Bonis 1973) } \\
\hline P. blandfordi & $71.5-75.5$ & $47.5-49.5$ & $(58.0)-64.5$ \\
\hline Bugti Hills (Antoine et al. 2010) & $73.6[5]$ & $48.1[5]$ & $62.5[5]$ \\
\hline D. lamilloquense & $76.7-78.5$ & $54.7-63.4$ & $69.5-73.5$ \\
\hline Castelmaurou (Duranthon 1990) & $77.6[2]$ & $59.05[2]$ & $71.5[2]$ \\
\hline $\begin{array}{l}\text { D. asphaltense } \\
\text { Saulcet (coll. NMB) }\end{array}$ & 90.0 & 62.0 & 86.0 \\
\hline D. aginense & $83.0-85.6$ & $50.0-55.1$ & $70.7-72.1$ \\
\hline Laugnac (coll. MHNM) & $84.5[3]$ & $51.9[3]$ & $71.5[3]$ \\
\hline D. aurelianense & $75.5-86.0$ & $72.6-77.0$ & $61.2-68.4$ \\
\hline $\begin{array}{l}\text { Neuville-aux-Bois (Cerdeño } \\
\text { 1993) }\end{array}$ & $81.4[3]$ & $74.8[2]$ & $63.8[3]$ \\
\hline $\begin{array}{l}\text { D. askazansorense } \\
\text { Askazansor (Kordikova 2001) }\end{array}$ & 85.0 & 49.0 & 73.8 \\
\hline
\end{tabular}

\section{Calcaneum}

D. lemanense

$65.5 \quad 124.4$

Wischberg (this study)

\begin{tabular}{|c|c|c|c|}
\hline $\begin{array}{l}\text { P. pleuroceros } \\
\text { Paulhiac (Bonis 1973) }\end{array}$ & - & $(54.8)$ & $(100.5)$ \\
\hline P. blandfordi & (67) & $55.0-63.0$ & $(97.0)-105.0$ \\
\hline Bugti Hills (Antoine et al. 2010) & & $59.7[3]$ & $104.0[2]$ \\
\hline $\begin{array}{l}\text { D. lamilloquense } \\
\text { La Milloque (Michel 1983) }\end{array}$ & - & 60.5 & - \\
\hline $\begin{array}{l}\text { D. lamilloquense } \\
\text { Castelmaurou (Duranthon 1990) }\end{array}$ & 73.0 & $\begin{array}{l}50.5-55.5 \\
53.0[2]\end{array}$ & $\begin{array}{l}107.0-115.0 \\
111.0[2]\end{array}$ \\
\hline $\begin{array}{l}\text { D. asphaltense } \\
\text { Pyrimont-Challonges (Type, } \\
\text { coll. UCBL) }\end{array}$ & 69.1 & 63.1 & 108.3 \\
\hline $\begin{array}{l}\text { D. asphaltense } \\
\text { Saulcet (coll. NMB) }\end{array}$ & 77.5 & 62.5 & 120.0 \\
\hline $\begin{array}{l}\text { D. aginense } \\
\text { Laugnac (coll. MHNM) }\end{array}$ & 72.2 & $\begin{array}{l}55.0-61.0 \\
58.5[4]\end{array}$ & $\begin{array}{l}104.5-115.2 \\
110.7[4]\end{array}$ \\
\hline D. aurelianense & $71.6-75.8$ & $50.5-62.5$ & $122.0-123.0$ \\
\hline $\begin{array}{l}\text { Neuville-aux-Bois (Cerdeño } \\
\text { 1993) }\end{array}$ & $73.7[2]$ & $56.5[2]$ & $122.5[2]$ \\
\hline D. askazansorense & 80.5 & 63.0 & 118.5 \\
\hline
\end{tabular}

Askazansor (Kordikova 2001) 


\section{Table $\mathbf{1 0}$ (on next page)}

Dimensions [mm] of the MtIl and MtIII of Diaceratherium lemanense (Perissodactyla, Rhinocerotidae) from Wischberg and comparisons with other Diaceratherium and Pleuroceros specimens.

Dimensions in parentheses are estimated and those in italics are based on the literature. Localities are indicated below the taxon name and those in bold font are the type localities of the species. The upper line indicates the minimum and maximum dimensions, and the bottom line (when several specimen are used) indicates the average value and the number of specimens (in brackets). 


\begin{tabular}{|c|c|c|c|c|c|c|c|}
\hline Metatarsals & $\mathbf{L}$ & $\begin{array}{l}\text { TD } \\
\text { prox }\end{array}$ & $\begin{array}{l}\text { APD } \\
\text { prox }\end{array}$ & $\begin{array}{l}\text { TD } \\
\text { dia }\end{array}$ & $\begin{array}{l}\text { APD } \\
\text { dia }\end{array}$ & $\begin{array}{l}\text { TD } \\
\text { dist }\end{array}$ & $\begin{array}{l}\text { APD } \\
\text { dist }\end{array}$ \\
\hline MtII & & & & & & & \\
\hline $\begin{array}{l}\text { D. lemanense } \\
\text { Wischberg (this study) }\end{array}$ & 130.6 & 31.7 & - & 32.1 & 16.3 & 36.2 & 29.5 \\
\hline $\begin{array}{l}\text { D. lemanense } \\
\text { Gannat (coll. NMB) }\end{array}$ & 134.0 & 30.0 & 42.0 & 27.0 & 24.0 & 41.0 & 37.5 \\
\hline $\begin{array}{l}\text { P. pleuroceros } \\
\text { Paulhiac (Bonis 1973) }\end{array}$ & $(111.0)$ & $(21.8)$ & $(28.5)$ & $(18.0)$ & $(15.0)$ & $(30.0)$ & - \\
\hline $\begin{array}{l}\text { P. blandfordi } \\
\text { Bugti Hills (Antoine et al. 2010) }\end{array}$ & 101.5 & 22.5 & 34.5 & 21.0 & 19.0 & $\begin{array}{l}28.0-30.0 \\
29.0[2]\end{array}$ & $\begin{array}{l}28.5-29.0 \\
28.75[2]\end{array}$ \\
\hline $\begin{array}{l}\text { D. lamilloquense } \\
\text { Castelmaurou (Duranthon 1990) }\end{array}$ & $\begin{array}{l}131.5-132.2 \\
131.9[2]\end{array}$ & $\begin{array}{l}27.0-27.0 \\
27.0[2]\end{array}$ & $\begin{array}{l}34.0-35.4 \\
34.7[2]\end{array}$ & $\begin{array}{l}22.0-24.0 \\
23.0[2]\end{array}$ & $\begin{array}{l}19.0-20.5 \\
19.8[2]\end{array}$ & $\begin{array}{l}33.4-34.0 \\
34.7[2]\end{array}$ & $\begin{array}{l}33.4-35.3 \\
34.4[2]\end{array}$ \\
\hline $\begin{array}{l}\text { D. asphaltense } \\
\text { Saulcet (coll. NMB) }\end{array}$ & 119.5 & 42.0 & 41.8 & 26.8 & 22.5 & 30.5 & 39.1 \\
\hline D. aginense & $104.9-113.4$ & $29.0-31.2$ & $34.3-37.3$ & $24.4-27.6$ & $19.0-22.3$ & $33.0-35.1$ & $35.6-38.9$ \\
\hline Laugnac (coll. MHNM) & $108.9[5]$ & $29.8[6]$ & $36.1[5]$ & $26.0[6]$ & $20.5[6]$ & $33.7[4]$ & 36.9 [4] \\
\hline D. aurelianense & 101.4 & 35.7 & 37.5 & 30.4 & 20.5 & 41.6 & 42.7 \\
\hline
\end{tabular}

Neuville-aux-Bois (Cerdeño

1993)

\section{MtIII}

\begin{tabular}{|c|c|c|c|c|c|c|c|}
\hline $\begin{array}{l}\text { D. lemanense } \\
\text { Wischberg (this study) }\end{array}$ & 146.9 & 47.4 & 35.5 & 45.4 & 16.3 & 47.3 & 30.6 \\
\hline $\begin{array}{l}\text { D. lemanense } \\
\text { Gannat (coll. NMB) }\end{array}$ & 153.0 & 54.5 & 44.0 & 42.0 & 20.0 & 59.0 & 40.0 \\
\hline $\begin{array}{l}\text { P. pleuroceros } \\
\text { Paulhiac (Bonis 1973) }\end{array}$ & - & $(42.0)$ & $(40.5)$ & $(37.5)$ & - & $(45.0)$ & - \\
\hline $\begin{array}{l}\text { P. blandfordi } \\
\text { Bugti Hills (Antoine et al. 2010) }\end{array}$ & - & 41.0 & $(34.0)$ & $\begin{array}{l}31.5-33.0 \\
32.8[2]\end{array}$ & $\begin{array}{l}15.5-16.0 \\
15.8[2]\end{array}$ & $\begin{array}{l}36.0-36.0 \\
36.0[2]\end{array}$ & $\begin{array}{l}30.0-32.5 \\
31.3[2]\end{array}$ \\
\hline $\begin{array}{l}\text { D. lamilloquense } \\
\text { Castelmaurou (Duranthon 1990) }\end{array}$ & $\begin{array}{l}141.5-144.0 \\
142.3[2]\end{array}$ & $\begin{array}{l}44.0-48.2 \\
46.1[2]\end{array}$ & $\begin{array}{l}34.0-36.4 \\
35.2[2]\end{array}$ & $\begin{array}{l}34.9-38.5 \\
36.7[2]\end{array}$ & $\begin{array}{l}17.2-18.3 \\
17.8[2]\end{array}$ & $\begin{array}{l}51.2-43.0 \\
47.1[2]\end{array}$ & $\begin{array}{l}36.3-39.4 \\
37.9[2]\end{array}$ \\
\hline $\begin{array}{l}\text { D. asphaltense } \\
\text { Pyrimont-Challonges (Type, } \\
\text { coll. UCBL) }\end{array}$ & 128.0 & $(39.0)$ & 42.5 & 39.4 & 18.0 & 51.1 & 33.5 \\
\hline $\begin{array}{l}\text { D. asphaltense } \\
\text { Saulcet (coll NMB) }\end{array}$ & 131.5 & 50.6 & 45.7 & 40.0 & 23.0 & 49.3 & 44.1 \\
\hline D. aginense & $122.5-131.3$ & $41.4-48.5$ & $38.2-44.8$ & $37.6-45.3$ & $18.2-21.0$ & $47.3-54.1$ & $39.6-42.1$ \\
\hline Laugnac (coll. MHNM) & $127.5[6]$ & $45.0[5]$ & $41.3[5]$ & $41.7[6]$ & $19.3[6]$ & $51.1[6]$ & $40.5[6]$ \\
\hline $\begin{array}{l}\text { D. aurelianense } \\
\text { Neuville-aux-Bois (Cerdeño } \\
\text { 1993) }\end{array}$ & $\begin{array}{l}117.0-118.0 \\
117.5[2]\end{array}$ & $\begin{array}{l}48.3-50.7 \\
49.8[2]\end{array}$ & 42.8 & $\begin{array}{l}40.5-43.8 \\
42.1[3]\end{array}$ & $\begin{array}{l}17.3-17.8 \\
17.6[2]\end{array}$ & $\begin{array}{l}53.2-54.0 \\
53.9[3]\end{array}$ & $\begin{array}{l}39.0-43.3 \\
41.2[2]\end{array}$ \\
\hline
\end{tabular}




\section{Table 11 (on next page)}

Occurrences of Diaceratherium (Perissodactyla, Rhinocerotidae) species in France, Switzerland and other countries.

Modified from Becker et al. (2009) with additions from Duranthon (1990, 1991), Antoine et al. (1997), Boada-Saña et al. (2007), Mennecart et al. (2012), Antoine \& Becker (2013) and Becker et al. (2018). Names in bold font indicate the type locality of the species. 


\begin{tabular}{|c|c|c|c|c|}
\hline \multirow{2}{*}{$\begin{array}{l}\mathrm{P}-\mathrm{MN} \\
\text { zones }\end{array}$} & \multirow[t]{2}{*}{ Taxa } & \multicolumn{3}{|l|}{ Localities } \\
\hline & & France & Switzerland & Others \\
\hline MN4 & $\begin{array}{l}D . \\
\text { aurelianense }\end{array}$ & Artenay & & $\begin{array}{l}\text { Areeiro da Barbuda (Portugal), Areeiro de Santa } \\
\text { Luzia (Portugal), Eggingen-Mittelhart } 3 \text { (=D. cf. } \\
\text { aurelianense; Germany), Quinta da Carrapata } \\
\text { (Portugal), Quinta da Noiva (Portugal), Quinta da } \\
\text { Trindade (Portugal), Quinta das Pedreiras } \\
\text { (Portugal), Quinta do Narigão (Portugal), Vale } \\
\text { Pequeno (Portugal) }\end{array}$ \\
\hline MN3 & $\begin{array}{l}\text { D. } \\
\text { aurelianense }\end{array}$ & $\begin{array}{l}\text { Neuville-aux-Bois, Beaulieu, Chilleurs-aux- } \\
\text { Bois, Chitenay, Esvres, La Brosse, Les } \\
\text { Beilleaux, Les Buissonneaux, Marsolan, } \\
\text { Mauvières, Navère, Ronville }\end{array}$ & $\begin{array}{l}\text { Brüttelen, } \\
\text { Cheyres, } \\
\text { La Molière }\end{array}$ & $\begin{array}{l}\text { Horta das Tripas (= D. cf. aurelianense; Portugal), } \\
\text { Molí Calopa (Spain), Rubielos de Mora (Spain), } \\
\text { Wintershof-West (Germany) }\end{array}$ \\
\hline $\mathrm{MN} 2 / 3$ & $\begin{array}{l}\text { D. } \\
\text { askazansorense }\end{array}$ & & & Askazansor (Kazakhstan) \\
\hline \multirow[t]{3}{*}{ MN2 } & D. aginense & $\begin{array}{l}\text { Laugnac, Auterive, Beaupuy, Calmont-St- } \\
\text { Cernin, Cintegabelle, Grépiac, Montaigu-le- } \\
\text { Blin, Pouvourville, Venerque }\end{array}$ & $\begin{array}{l}\text { Engehalde, } \\
\text { La Chaux, } \\
\text { Lausanne, } \\
\text { Sous-le- } \\
\text { Mont }\end{array}$ & Hessler (Germany) \\
\hline & $\begin{array}{l}\text { D. } \\
\text { aurelianense }\end{array}$ & & & Loranca del Campo (= D. cf. aurelianense; Spain) \\
\hline & D. lemanense & $\begin{array}{l}\text { Barbotan-les-Thermes, Cindré, Gans, Laugnac, } \\
\text { Montaigu-le-Blin, Selles-sur-Cher, St-Gérand- } \\
\text { le-Puy }\end{array}$ & Engehalde & $\begin{array}{l}\text { Budenheim (Germany), Ulm-Michelsberg } \\
\text { (Germany) }\end{array}$ \\
\hline \multirow[t]{2}{*}{ MN1 } & D. aginense & Gannat, Paulhiac & & \\
\hline & D. asphaltense & Pyrimont-Challonges, Saulcet & & \\
\hline
\end{tabular}




\begin{tabular}{|c|c|c|c|c|}
\hline & D. lemanense & $\begin{array}{l}\text { Gannat, Bazas, Bézac, Caignac, Casteljaloux- } \\
\text { Balade, Cindré, Ginestous, Grenade-sur- } \\
\text { Garonne, Labastide-Beauvoir, Pechbonnieu, La } \\
\text { Roche-Blanche-Gergovie, Paulhiac, Pech David, } \\
\text { Randan, St-Loup Cammas, St-Michel-du-Touch, } \\
\text { Saulcet, Saverdun, Toulouse Borderouge, } \\
\text { Toulouse Embouchure }\end{array}$ & Wischberg & $\begin{array}{l}\text { Finthen (Germany), Oppenheim (Germany), } \\
\text { Weisenau (Germany) }\end{array}$ \\
\hline & $\begin{array}{l}\text { D. } \\
\text { tomerdingense }\end{array}$ & & & Tomerdingen (Germany) \\
\hline MP30/MN1 & D. asphaltense & & Bühler & \\
\hline MP30 & D. lemanense & $\begin{array}{l}\text { Billy, Gannat « sommet », Thézels (=D. aff. } \\
\text { lemanense), Toulouse-Borderouge }\end{array}$ & & Rott bei Bonn (Germany) \\
\hline MP29 & $\begin{array}{l}\text { D. } \\
\text { lamilloquense }\end{array}$ & $\begin{array}{l}\text { La Milloque, Castelmaurou, Castelnau } \\
\text { d'Estretefonds, Dieupentale }\end{array}$ & Rickenbach & \\
\hline
\end{tabular}




\section{Table 12 (on next page)}

Estimates of rhinocerotid species body mass from Wischberg locality, Bern Canton, Swiss Molasse basin (MN1, Agenian, earliest Miocene).

Based on the allometric correlations with the occlusal surface of the first lower molar (Legendre, 1989), the transverse width of the tibial trochlea of the astragalus (Li1; Tsubamoto, 2014) and various femoral and tibial measurements (Fortelius \& Kappelman, 1993). 


\begin{tabular}{|c|c|c|c|}
\hline Legendre 1989 & mean L m1 & mean W m1 & Estimated body mass (kg) \\
\hline $\begin{array}{l}\text { Diaceratherium lemanense } \\
\text { NMBE5026738 }\end{array}$ & 42.8 & 28.5 & 1,730 \\
\hline $\begin{array}{l}\text { Diaceratherium lemanense } \\
\text { casts NMBE5031541 and NMB-AS76 }\end{array}$ & 40.5 & 26.5 & 1,417 \\
\hline $\begin{array}{l}\text { Pleuroceros pleuroceros } \\
\text { casts NMBE } 5031553 \text { and NMB-AS77 }\end{array}$ & 29.7 & 18.6 & 504 \\
\hline Tsubamoto 2014 & & Li1 & \\
\hline $\begin{array}{l}\text { Diaceratherium lemanense } \\
\text { Astragalus NMB } 698\end{array}$ & & 65.7 & 937 \\
\hline $\begin{array}{l}\text { Diaceratherium lemanense } \\
\text { Astragalus NMB } 2017\end{array}$ & & 69.7 & 1,105 \\
\hline Fortelius \& Kappelman 1993 & & F1 & \\
\hline $\begin{array}{l}\text { Diaceratherium lemanense } \\
\text { Femur NMBE5031542 }\end{array}$ & & 500 & 1,624 \\
\hline Fortelius \& Kappelman 1993 & & F5 & \\
\hline $\begin{array}{l}\text { Diaceratherium lemanense } \\
\text { Femur NMBE5031542 }\end{array}$ & & 132 & 1,261 \\
\hline Fortelius \& Kappelman 1993 & & T2 & \\
\hline $\begin{array}{l}\text { Diaceratherium lemanense } \\
\text { Tibia NMBE5031544 }\end{array}$ & & 123 & 1,365 \\
\hline Fortelius \& Kappelman 1993 & & T4 & \\
\hline $\begin{array}{l}\text { Diaceratherium lemanense } \\
\text { Tibia NMBE5031544 }\end{array}$ & & 88 & 1,104 \\
\hline Fortelius \& Kappelman 1993 & & T5 & \\
\hline $\begin{array}{l}\text { Diaceratherium lemanense } \\
\text { Tibia NMBE5031544 }\end{array}$ & & 53 & 715 \\
\hline
\end{tabular}


Figure 1

General setting of Wischberg locality, Bern Canton, Swiss Molasse basin (MN1, Agenian, earliest Miocene).

(A) Map of a part of Western Europe showing the location of Switzerland. (B) Enlargement of the Aquitanian palaeogeographical context of the Swiss Molasse Basin, with detailed location of Wischberg locality (star symbol).

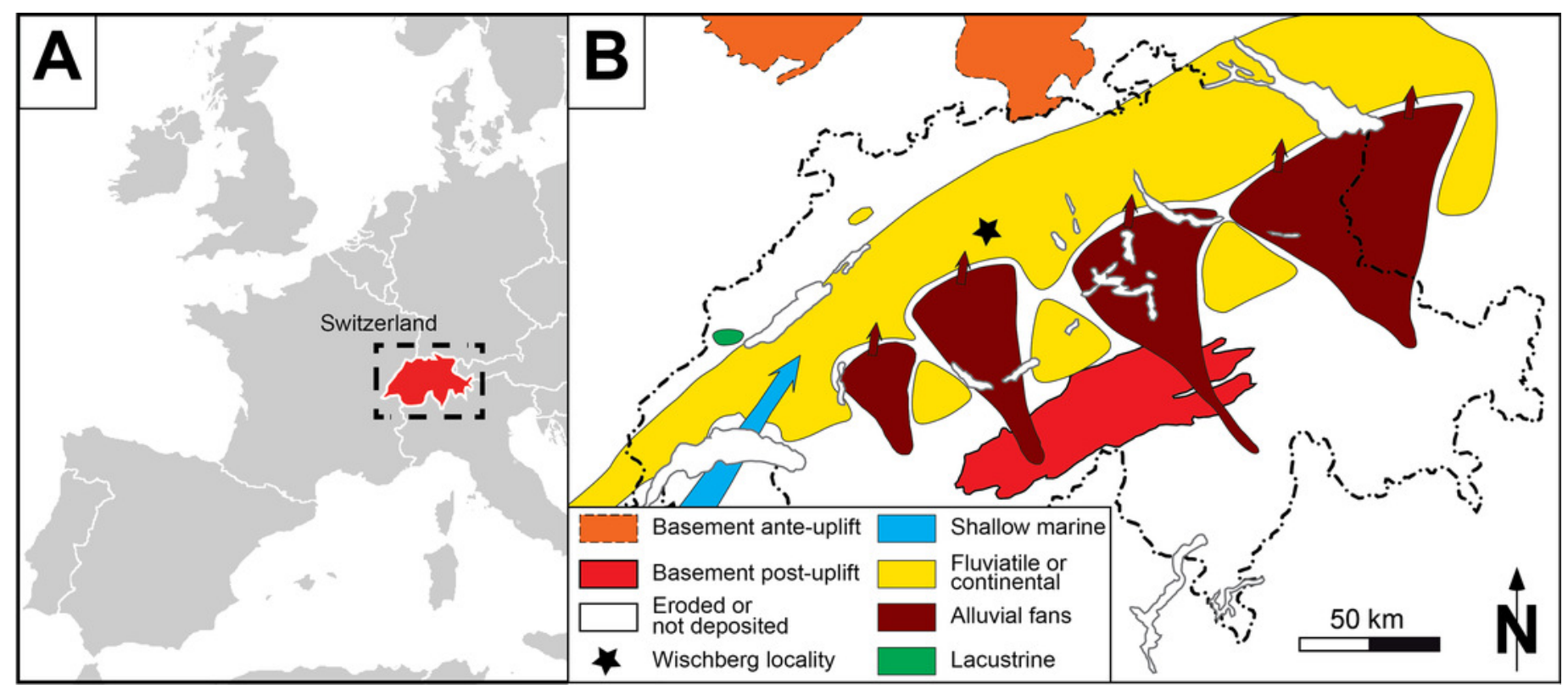




\section{Figure 2}

Pleuroceros pleuroceros (Perissodactyla, Rhinocerotidae) from Wischberg locality, Bern Canton, Swiss Molasse basin (MN1, Agenian, earliest Miocene).

Partial skull NMBE5031553 in lateral (A), dorsal (B), medial (C) and occlusal (D) views and left-side fragment with P2-M3 from the same individual in occlusal (E) view. Mandible fragments NMBE5026739 in labial $(F, G)$, lingual $(H, I)$ and occlusal $(J, K)$ views with p4-m3 (right-side fragment) and m1-2 (left-side fragment). Photo credit: Patrick Röschli. 
A

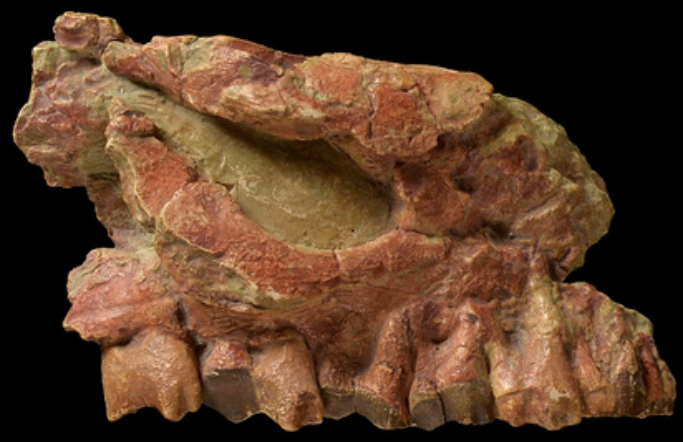

C

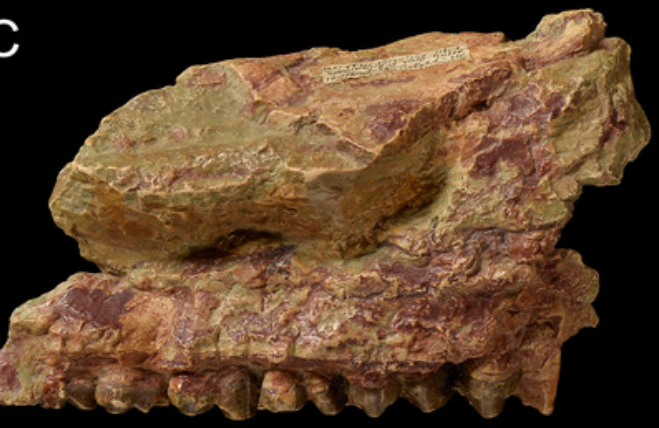

F
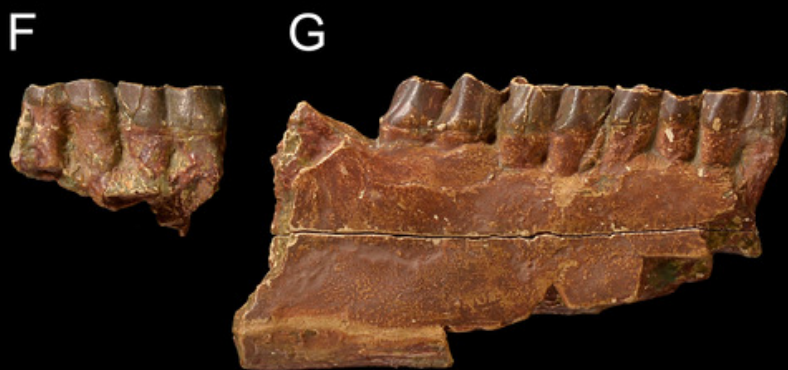

$\mathrm{J}$ menกง
$\mathrm{K}$

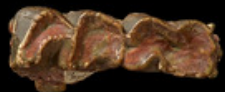

B

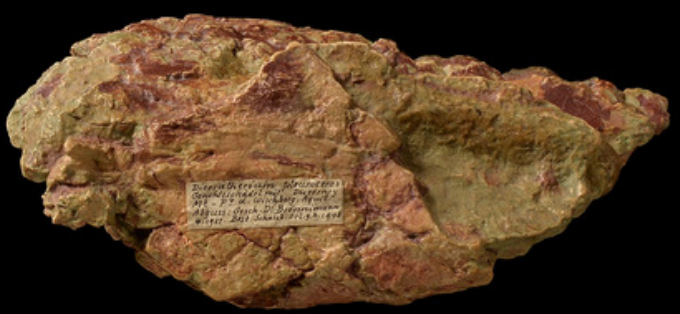

D

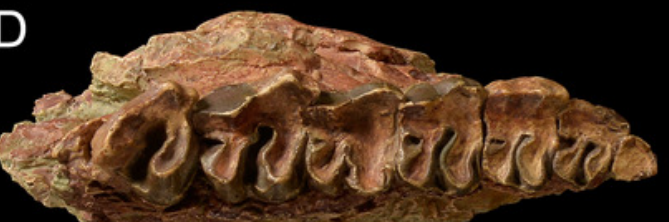

$\mathrm{E}$

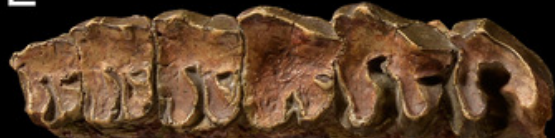

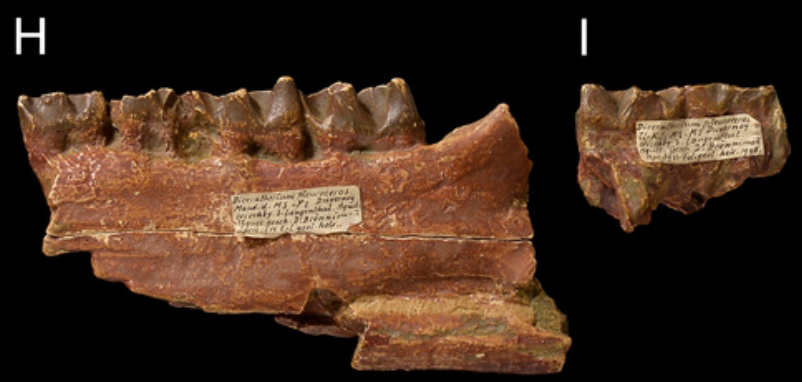




\section{Figure 3}

Pleuroceros pleuroceros (Perissodactyla, Rhinocerotidae) from Wischberg locality, Bern Canton, Swiss Molasse basin (MN1, Agenian, earliest Miocene).

Right semilunate NMBE5031537 in anterior (A), proximal (B), distal (C), lateral (D) and medial (E) views and right McIV (cast NMB-AS79) in anterior (F), lateral (G), posterior $(H)$, medial $(\mathrm{I})$ and proximal with dorsal toward top (J) views. Photo credit: Patrick Röschli.

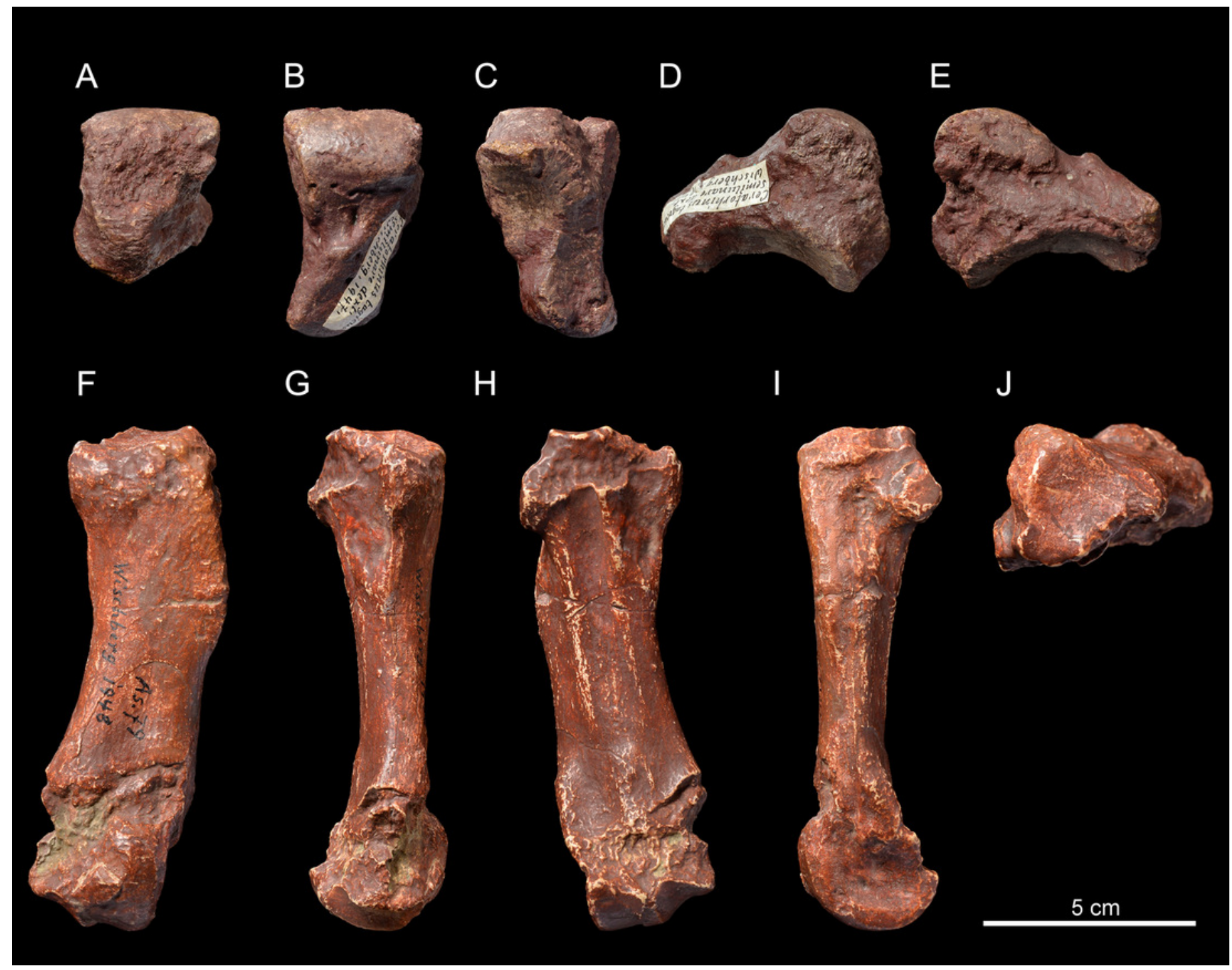




\section{Figure 4}

Diaceratherium lemanense (Perissodactyla, Rhinocerotidae) from Wischberg locality, Bern Canton, Swiss Molasse basin (MN1, Agenian, earliest Miocene).

Skull NMBE5031538 in laterodorsal (A), ventral (B) and occipital (C) views. Right hemimandible NMBE5026738 in labial (D), lingual (E) and occlusal (F) views with an enlarged occlusal view of the teeth $(G)$. Right maxillary fragment NMBE5031539 in labial $(H)$, lingual (I) and occlusal (J) views with an enlarged occlusal view of the teeth (K). Photo credit: Patrick Röschli. 


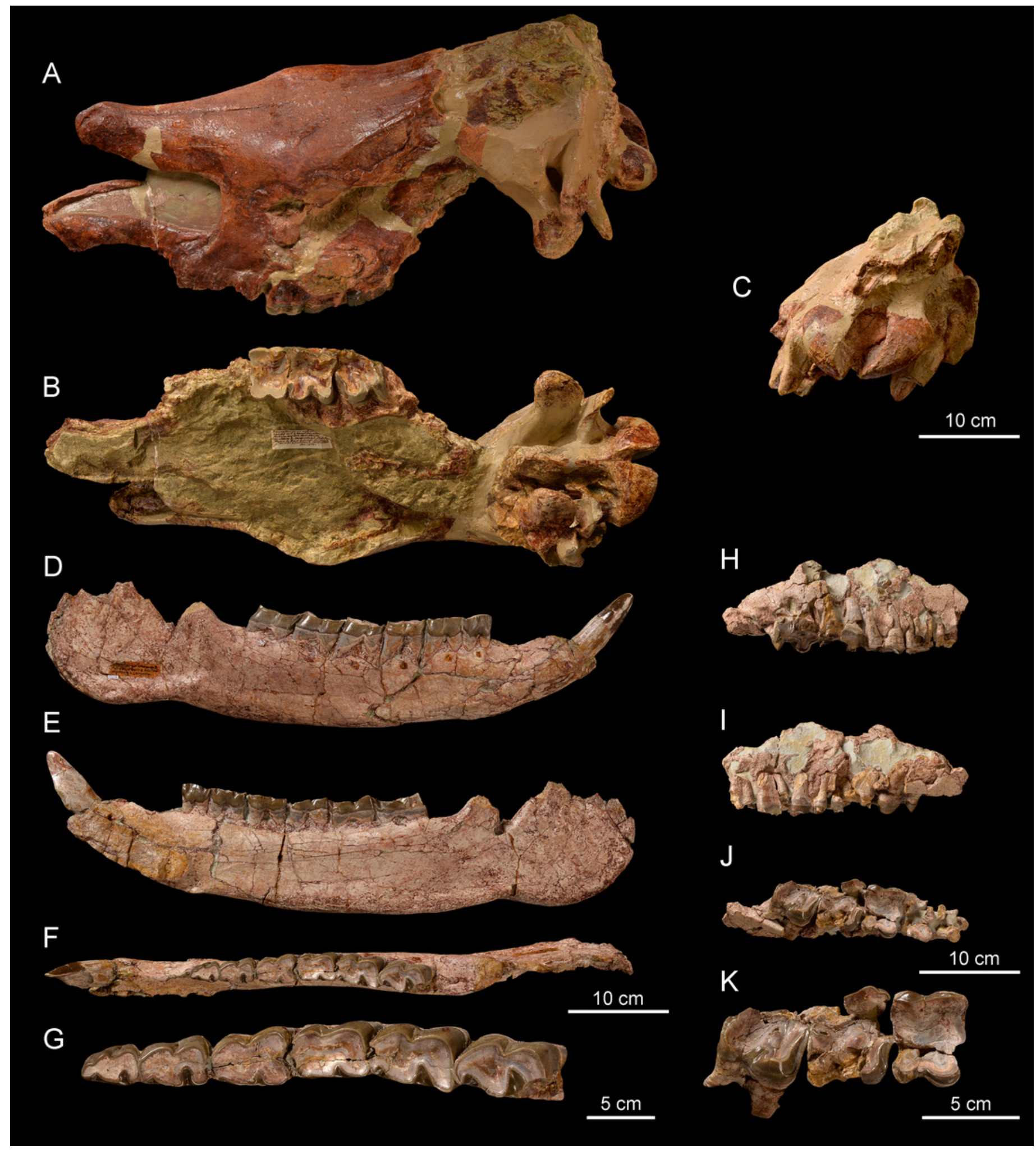




\section{Figure 5}

Diaceratherium lemanense (Perissodactyla, Rhinocerotidae) from Wischberg locality, Bern Canton, Swiss Molasse basin (MN1, Agenian, earliest Miocene).

Left I1 NMBE5031540 in occlusal (A), lingual (B) and labial (C) views. Right II NMBE5031546 in occlusal (D), lingual (E) and labial (F) views. Right II NMBE5031540 in occlusal (G), lingual (H) and labial (I) views. Left i2 NMBE5031547 in occlusal (J), lingual (K) and labial (L) views. Left P3 NMBE5031549 in occlusal (M) and lingual (N) views. Right P3 NMBE5031550 in occlusal (O) and lingual (P) views. Fragmentary right P1 NMBE5031548 in occlusal (Q), lingual (R) and labial (S) views. Fragmentary left p4 NMBE5031551 in occlusal (T), lingual (U) and labial (V) views. Photo credit: Patrick Röschli. 


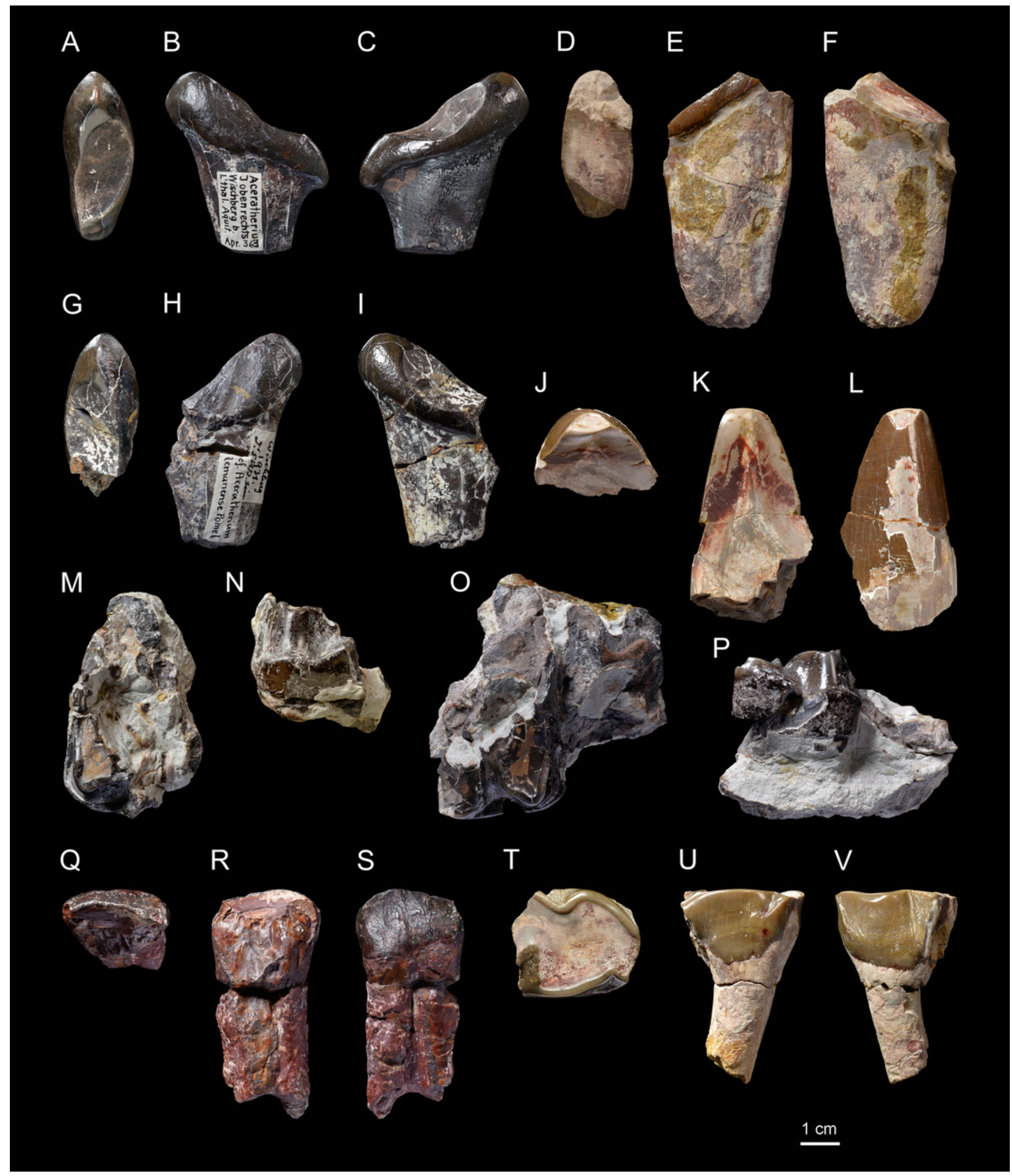




\section{Figure 6}

Diaceratherium lemanense (Perissodactyla, Rhinocerotidae) from Wischberg locality, Bern Canton, Swiss Molasse basin (MN1, Agenian, earliest Miocene).

Right femur NMB-UM6314 in anterior (A), medial (B), posterior (C) and lateral (D) views. Right tibia NMBE5031544 in anterior (E), medial $(F)$, posterior $(G)$ and lateral $(H)$ views. Photo credit: Patrick Röschli. 


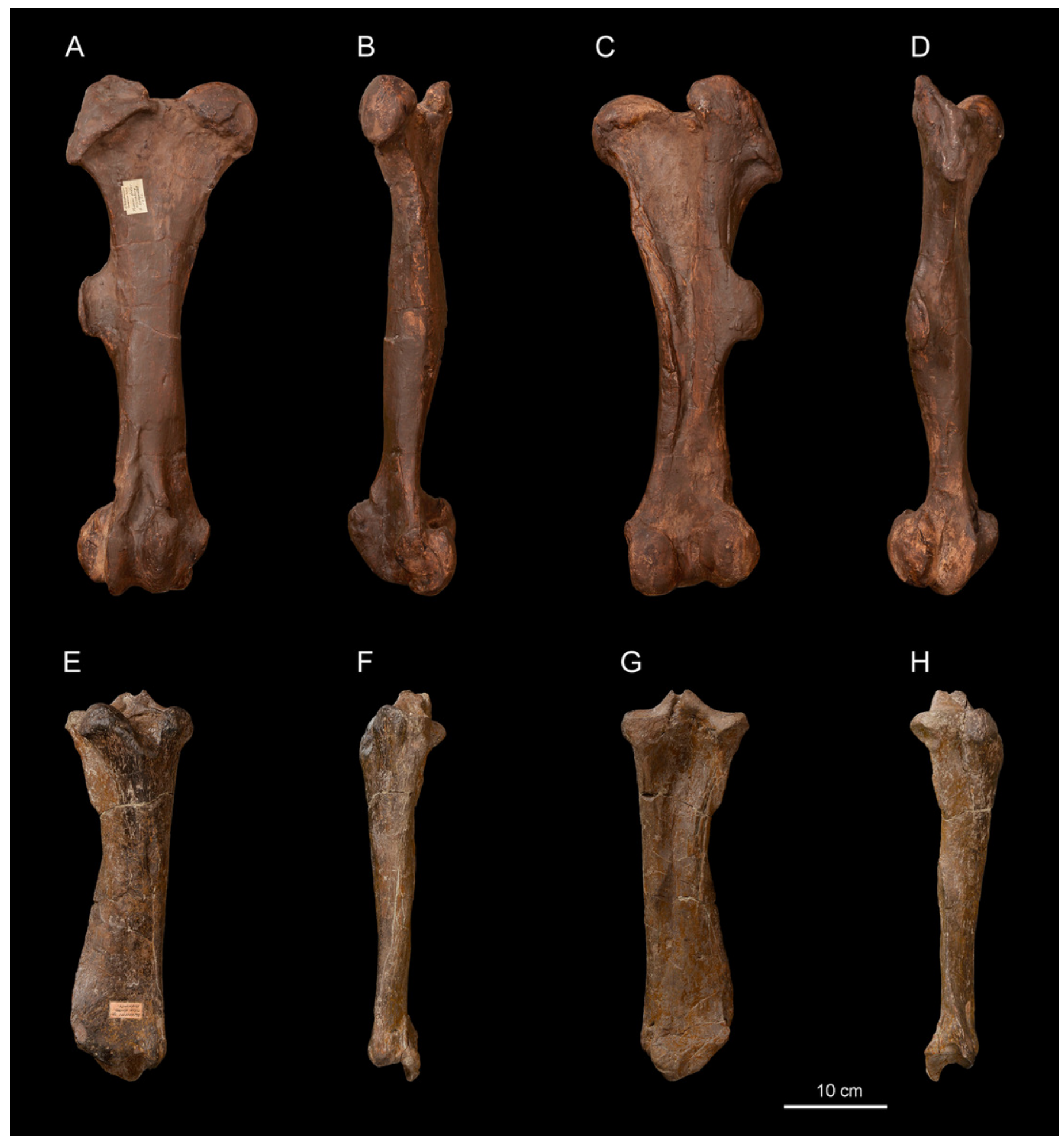




\section{Figure 7}

Diaceratherium lemanense (Perissodactyla, Rhinocerotidae) from Wischberg locality, Bern Canton, Swiss Molasse basin (MN1, Agenian, earliest Miocene).

Right astragalus NMB-2017 in anterior (A) posterior (B) and distal (C) views. Right astragalus NMB-698 in anterior (D) posterior (E) and distal (F) views. Right calcaneus NMBE5031545 in distal (G), anterior $(\mathrm{H})$, lateral (I), posterior (J) and medial (K) views. Right MtIII NMBE5026811 in anterior $(\mathrm{L})$, lateral $(\mathrm{M})$, posterior $(\mathrm{N})$, medial $(\mathrm{O})$ and proximal with dorsal toward top $(\mathrm{P})$ views. Right MtII NMBE5026812 in proximal with dorsal toward top (Q), anterior (R), lateral (S), posterior (T) and medial (U) views. Photo credit: Patrick Röschli. 


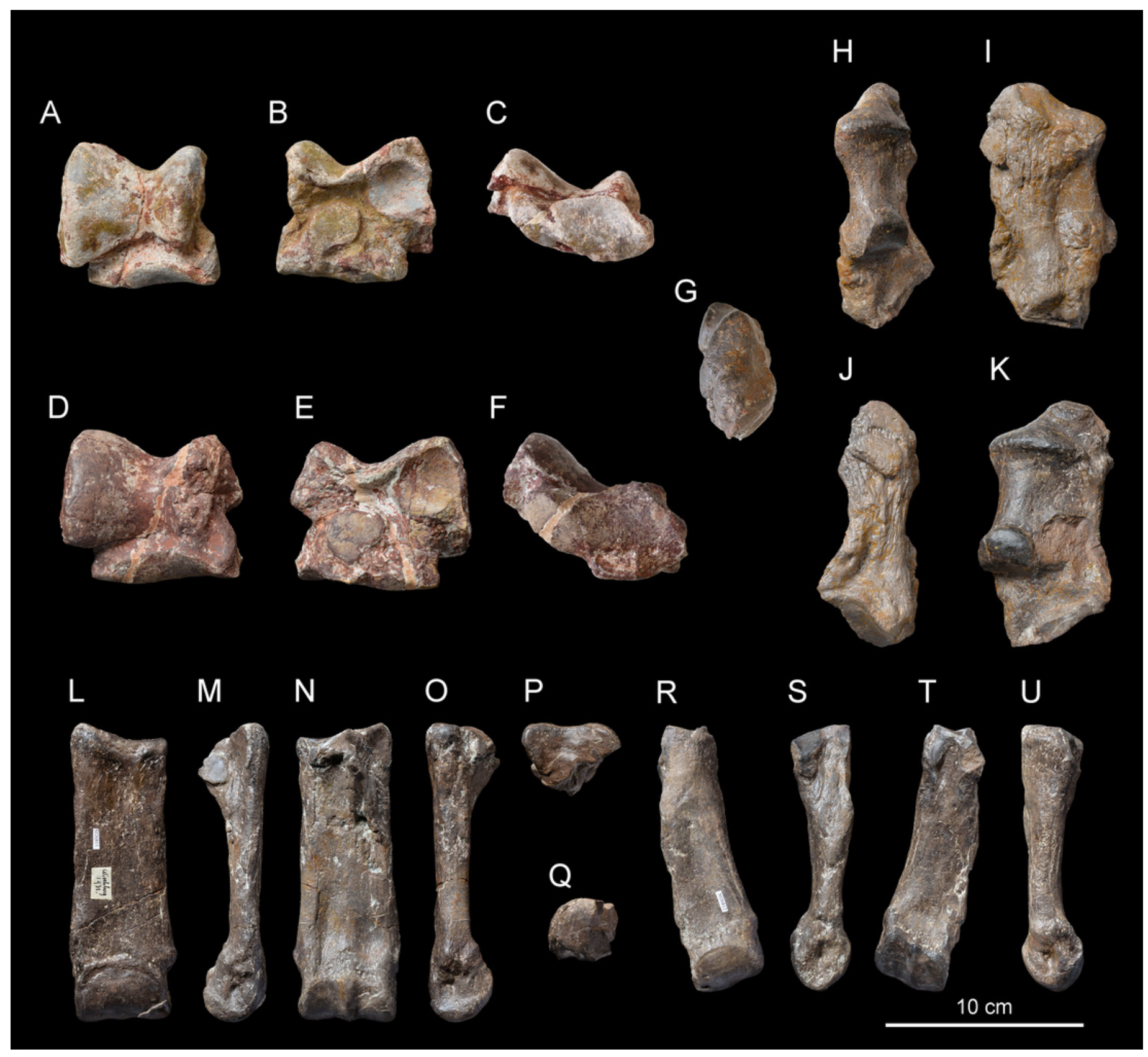




\section{Figure 8}

Comparison of the skulls of Diaceratherium (Perissodactyla, Rhinocerotidae).

(A) D. asphaltense (NMSG-F13607) from Bühler (MP30-MN1; Becker et al. 2018). (B) D. apshaltense (NMB Sau 1662) from Saulcet (MN1). (C) D. aurelianense

(MHNT.PAL.2013.0.1001, cast of the holotype) from Neuville-aux-Bois (MN3). (D) D. aginense (FSL collection) from Laugnac (MN2). (E) D. lemanense (MNHN-AC-2375, holotype) from Gannat (MN1). (F) D. lemanense (cast NMBE5031538) from Wischberg (MN1). 


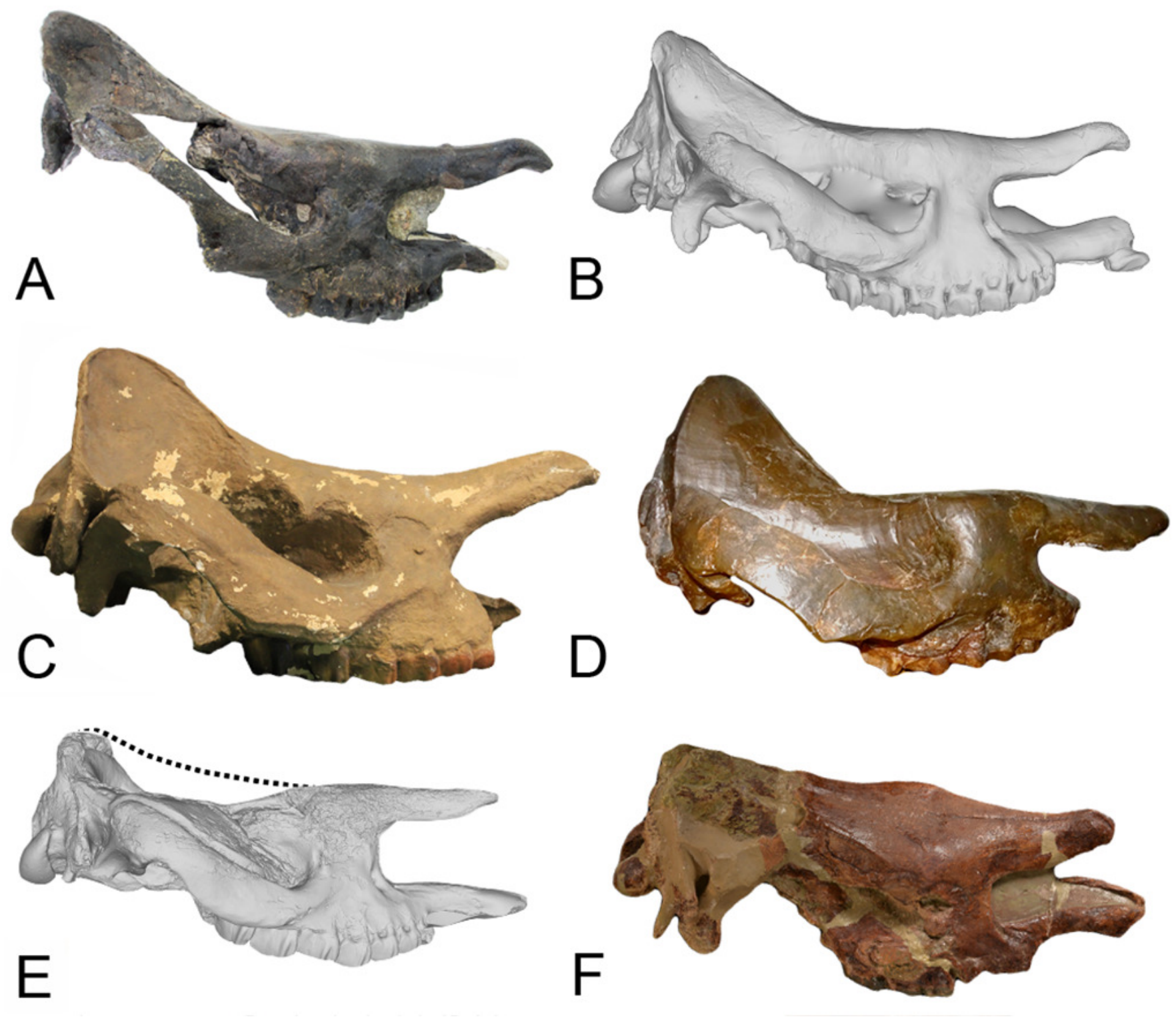

